\title{
Ophicarbonates of the Feragen Ultramafic Body, central Norway
}

\author{
Kristina G. Dunkel ${ }^{1, a}$, Bjørn Jamtveit ${ }^{1, b}$ \& Håkon Austrheim ${ }^{1, c}$ \\ ${ }^{1}$ Physics of Geological Processes (PGP), The Njord Centre, University of Oslo, P.O. Box 1048 Blindern, 0136 Oslo, Norway. \\ aORCID: 0000-0002-4100-381X \\ bORCID: 0000-0001-5700-1803 \\ cORCID: 0000-0002-8521-4547 \\ E-mail corresponding author (Kristina G. Dunkel): kristina.dunkel@geo.uio.no
}

\begin{abstract}
The carbonation of ultramafic rocks is a common alteration process in ophiolites and can occur in various settings. We provide the first detailed description of the carbonated peridotites (ophicarbonates) of the Feragen Ultramafic Body, central Norway, which have unusually variable compositions and microstructures. Lithologies range from pervasively carbonated serpentinites through carbonated serpentinite breccias to carbonated ultramafic conglomerates. Carbonate phases are Ca-carbonate, magnesite and dolomite. Some breccias are also cemented by coarsegrained brucite. This variability records strong variations in fluid chemistry and/or pressure and temperature conditions, both spatially and temporally. By analysing these altered ultramafic rocks using field relationships, optical microscopy, electron microprobe analysis and oxygen and carbon isotope compositions, we elucidate the history of the Feragen Ultramafic Body in more detail and emphasise the importance of deformation for the extent and type of alteration.
\end{abstract}

Keywords: carbonation, serpentinite, hydrothermalism, stable isotopes

Electronic Supplement 1: Carbonate compositions

Electronic Supplement 2: Silicate and hydroxide compositions

Received 21. December 2018 / Accepted 31. May 2019 / Published online 26. September 2019

\section{Introduction}

There is a multitude of geological settings, fluids and temperatures at which ultramafic rocks are carbonated. Ophicarbonates (rocks comprising both carbonate and serpentine) form at passive margins (Milliken \& Morgan, 1996; Schwarzenbach et al., 2013), at slow spreading ridges and oceanic transform faults (Kelley et al., 2005; Ludwig et al., 2006), and in peridotites cropping out on the continent (Kelemen \& Matter, 2008). The fluids can be warmer, uprising hydrothermal fluids, colder marine or meteoric waters, or a mixture of hydrothermal fluid and seawater. The carbonation of ultramafic rocks is a significant part of the hydrothermal circulation in the oceanic crust (Beard \& Hopkinson, 2000; Ludwig et al., 2006). In particular, the formation of ophicarbonates has been linked to white smokers (Ludwig et al., 2006); carbonate veining may represent paleostockwork systems such as those under the Lost City Hydrothermal Field (Kelley et al., 2005).

Bernoulli \& Weissert (1985) distinguished two main types of carbonate in ultramafic rocks: sedimentary carbonates, and carbonate cement crystallised directly from pore fluid. According to these authors, the analysis of present-day formation of ophicarbonates has shown 
that most ophicalcites are of tectonic-sedimentary origin. The carbonate phase, at least if produced during carbonation of the oceanic crust, is typically calcite; therefore, 'ophicalcite' is the most common term to describe carbonated ultramafic rocks. We use 'ophicarbonate' here, since calcite, magnesite, and dolomite occur in the carbonate-bearing ultramafic rocks of the Feragen Ultramafic Body (FUB), which we investigated. We provide the first detailed description of these ophicarbonates. Previously, Moore \& Hultin (1980) mentioned the occurrence of magnesite in ultramafic rocks of the FUB but did not go in detail. Using field relationships, optical microscopy, electron microprobe analysis, and oxygen and carbon isotope analysis, we thoroughly describe and characterise these rocks and discuss their formation.

\section{Geological setting}

\section{Regional geology}

The Feragen Ultramafic Body (FUB) in Sør-Trøndelag, Norway (Fig. 1), is one of several ultramafic bodies occurring along the southern and eastern margins of the Trondheim Nappe Complex (Nilsson et al., 1997, 2005, Nilsson \& Roberts, 2014) and crops out over an area of about $15 \mathrm{~km}^{2}$. Partly serpentinised massive dunites and other peridotites as well as harzburgite and chromite layers make up the majority of the FUB. The FUB is positioned at the margin of the Devonian Røragen basin, an intramontane collapse basin like the Devonian basins of western Norway (Séguret et al., 1989). The northern contact is covered by a Devonian conglomerate (Roberts,

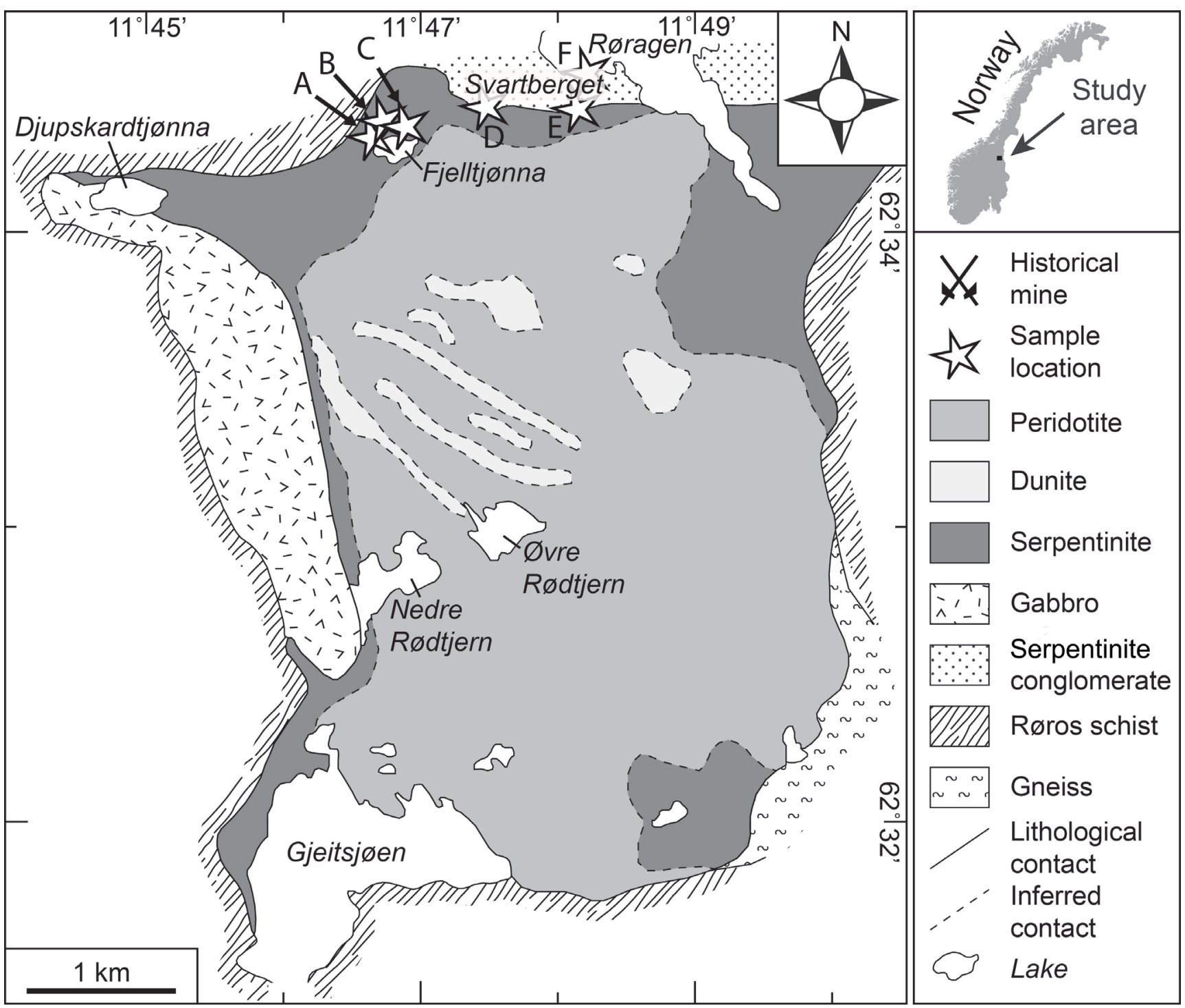

Figure 1. Simplified geological map of the Feragen Ultramafic Body (modified from Beinlich \& Austrheim, 2012, after Moore \& Hultin, 1980) with the sampled outcrops A to D in the north. Locality F consists of several outcrops in the serpentinite conglomerate at 'Svartberget'. 
1974). Close to the contact, the conglomerate consists solely of ultramafic material. A few hundred metres away from the contact, this monomict serpentinite conglomerate gives way to a polymict conglomerate with clasts of greenstone, schist and altered ultramafic material with layers of red-sandstone (Beinlich et al., 2018). Goldschmidt (1913) first described Middle Devonian plant fossils from the sedimentary rocks of the Røragen basin. Precambrian gneiss borders the FUB in the southeast and gabbro in the west (Moore \& Hultin, 1980).

Along the northern boundary of the FUB, where the degree of serpentinisation is highest (up to 100\%) and the present work was carried out, Moore \& Hultin (1980) described local occurrences of magnesite as anhedral, disseminated crystals in serpentinite or associated with talc. They interpreted the magnesite to have formed after serpentinisation. Recent carbonation on the surface of mine shafts in the FUB has been described by Beinlich \& Austrheim (2012), who found coatings of hydrous magnesium carbonates on serpentinised peridotites. In contrast, our focus here lies on the fossil ophicarbonates found in the same area.

\section{Overview over sampling sites}

All of the investigated outcrops are situated along the northern border of the FUB (Fig. 1). Most of the carbonate/hydroxide occurrences have a limited spatial extent and can only be observed in single outcrops. The outcrops (A to F) are shown in Fig. 1, for the exact sampling positions see Table 1. The specific outcrop conditions of samples taken in 2007 are not known; therefore, the outcrops are denoted with a prime mark in these cases (B' and F'). A summary of the outcrops, the different rock types occurring at them, and the respective samples is presented in Fig. 2. This sketch also includes interpretations regarding the type of alteration, which will be discussed later.

North of the lake Fjelltjønna, three sites have been investigated: At the westernmost outcrop (A), pervasively carbonated schistose serpentinites occur. In the middle (B), carbonate-cemented serpentinite breccias crop out. In the east (C), a brucite-rich serpentinite breccia is located between deformed serpentinite. The majority of the ridge Svartberget (Fig. 1) is composed of conglomerates with ultramafic clasts and, subordinately, carbonate clasts, and a carbonate matrix (F). The conglomerate has been sampled at different places along Svartberget. West of Svartberget, serpentinite containing cryptocrystalline magnesite crops out (D). The southern edge of Svartberget is a subvertical fault with a locally very smooth, almost mirror-like surface, which strikes approximately E-W. Locally, a dolomite-bearing carbonated serpentinite breccia occurs along this wall (E).
Table 1. Ophicarbonate sample outcrops in the Feragen Ultramafic Body.

\begin{tabular}{|c|c|c|c|}
\hline Sample & Easting & Northing & Outcrop \\
\hline I1-14 & 642652 & 6940984 & A \\
\hline I3-14 & 642659 & 6940995 & A \\
\hline I4- 14 & 642658 & 6941002 & A \\
\hline I6-14 & 642622 & 6941020 & A \\
\hline I7-14 & 642622 & 6941020 & A \\
\hline OC05-14 & & & B \\
\hline OC07-14 & & & B \\
\hline OC06-14 & 642717 & 6941107 & B \\
\hline OC03-16 & 642712 & 6941101 & B \\
\hline RøR02a & 642783 & 6941156 & $\mathrm{~B}^{\prime}$ \\
\hline RØR02b & 642783 & 6941156 & $\mathrm{~B}^{\prime}$ \\
\hline OC08-14 & 642874 & 6941085 & C \\
\hline F-6 & 643405 & 6941255 & D \\
\hline OC09-14 & 643402 & 6941253 & D \\
\hline OC02-16 & 643395 & 6941248 & D \\
\hline OC03-14 & 643846 & 6941262 & E \\
\hline OC10-14 & & & E \\
\hline Rør16-10a & & & $E^{\prime}$ \\
\hline OC02-14 & 644015 & 6941315 & $\mathrm{~F}$ \\
\hline RØR09 & 643471 & 6941252 & F \\
\hline Rør10/07 & 644012 & 6941301 & F \\
\hline Rør11/07 & 643683 & 6941269 & $F^{\prime}$ \\
\hline Rør12/07 & & & F \\
\hline Rør13/07 & & & $F^{\prime}$ \\
\hline Rør16/07 & 645901 & 6941259 & F' \\
\hline
\end{tabular}

\section{Methods}

Thin-sections made from hand samples and mini-cores were analysed with polarising light microscopy.

Major element compositions were measured by wavelength-dispersive spectrometry (WDS) with a Cameca SX 100 electron microprobe (Department of Geosciences, University of Oslo, Norway), using an acceleration voltage of $15 \mathrm{kV}$ and beam currents between 10 and $20 \mathrm{nA}$. Counting times were $10 \mathrm{~s}$ on peak and $5 \mathrm{~s}$ on background. Backscatter electron (BSE) images were acquired with the Cameca SX 100 electron microprobe and a Hitachi SU5000 FE-SEM (Department of Geosciences, University of Oslo). 


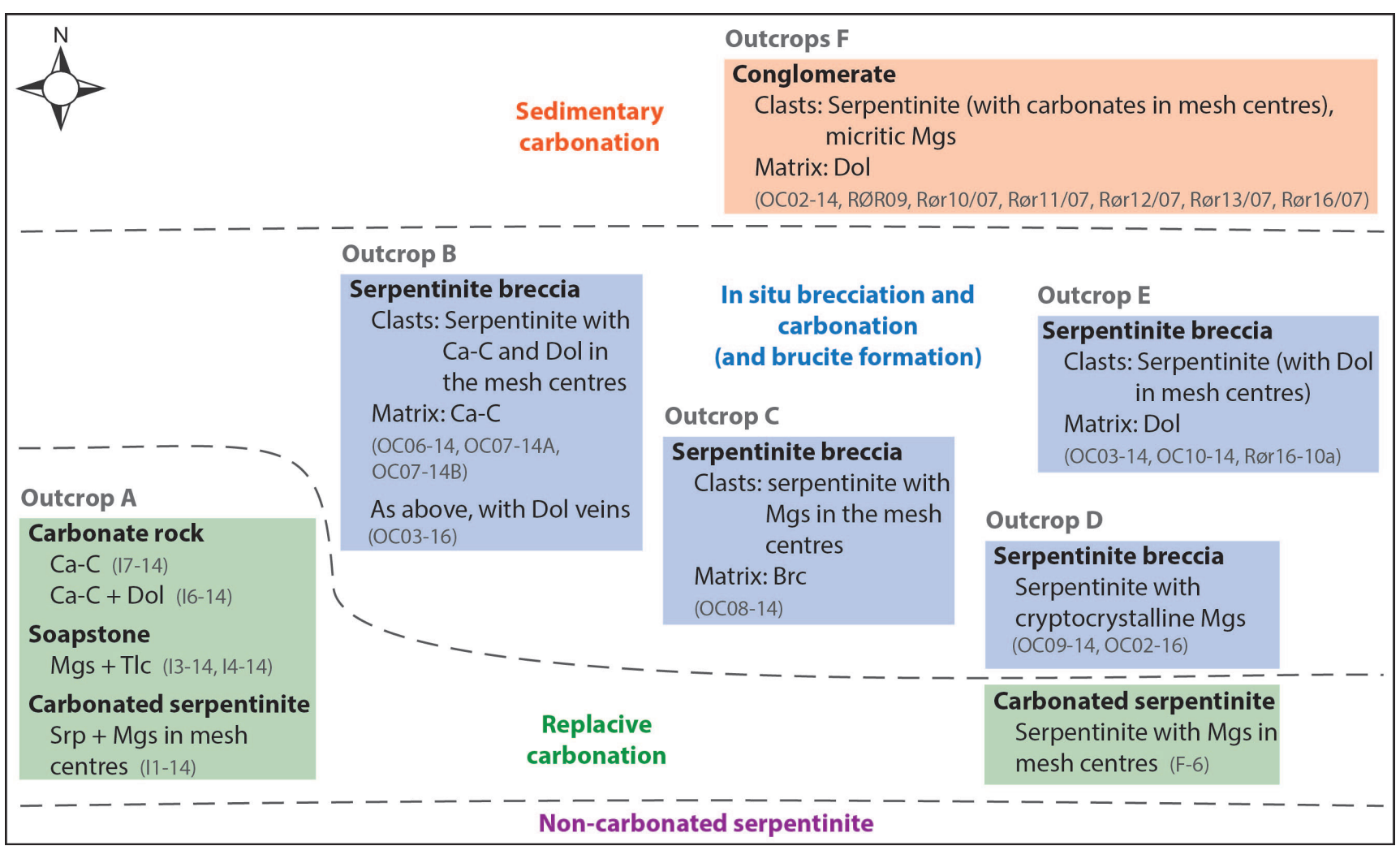

Figure 2. Summary sketch of the outcrops and associated rock types, alteration minerals, and respective samples. The outcrops are placed roughly according to their geographical position (see Fig. 1). For explanations regarding the different alteration types, see discussion. Abbreviations: Brc - brucite, Ca-C - Ca-carbonate, Dol - dolomite, Mgs - magnesite, Srp - serpentine, Tlc - talc.

Carbonate oxygen and carbon isotopes were determined on three different mass spectrometers. All samples were first investigated with electron microscopy to identify the carbonate phase. Samples acquired during a previous field trip in 2007, from outcrops B' and F', were measured at the Stable Isotope Laboratory at the Institute for Energy Technology (IfE) in Kjeller, Norway, on a Finnigan MAT DeltaXP isotope ratio mass spectrometer. IAEA-CO-1 reference material was analysed as unknown in all batches. Isotope ratios of samples from the years 2014 and 2016 were measured on a ThermoFinnigan MAT 253 IRMS with attached Kiel IV carbonate preparation device for calcite and a ThermoFinnigan Delta V IRMS coupled to a Gasbench II for samples containing magnesite and/or dolomite. Standardisation was done using NBS-19 and NBS-18 as well as internal working standards.

Isotopic compositions are reported relative to $\mathrm{V}-\mathrm{PDB}$ for carbon and SMOW for oxygen. Based on repeated analysis of laboratory standards, the precision of all results is $0.1 \%$ ( 2 sigma).

\section{Results}

\section{Macro- and microstructures of alteration}

Outcrop A: Carbonated serpentinites, soapstones, and carbonate rocks

Northwest of lake Fjelltjønna, three different rock types with varying carbonate/serpentine ratio and microstructure crop out (Fig. 3A).

The southern part of the outcrop consists of greyish serpentinites with an interlocking microstructure. Dendritic magnesite occurs throughout the samples (Fig. $3 \mathrm{~B})$, presumably replacing serpentine. This magnesite is commonly associated with pores. Dolomite occurs in veinlets, which may be lined with magnesite. Local microshearzones of schistose serpentine cross-cut the sample.

Several metres farther north soapstones occur which are foliated and have a reddish colour. Sample I3-14 consists mainly of magnesite of very different grain sizes. Some domains have grain sizes in the order of hundreds of $\mu \mathrm{m}$ diameter, while others contain magnesite of diameters less than $10 \mu \mathrm{m}$. Between them, there are intergrowths of talc and chlorite. Sample I4-14 contains large magnesite patches (similar to those in I1-14) in a talc-chlorite mixture. In both I3-14 and I4-14, the magnesite is cut and surrounded by areas of higher $\mathrm{FeCO}_{3}$ content (Fig. 3C). 

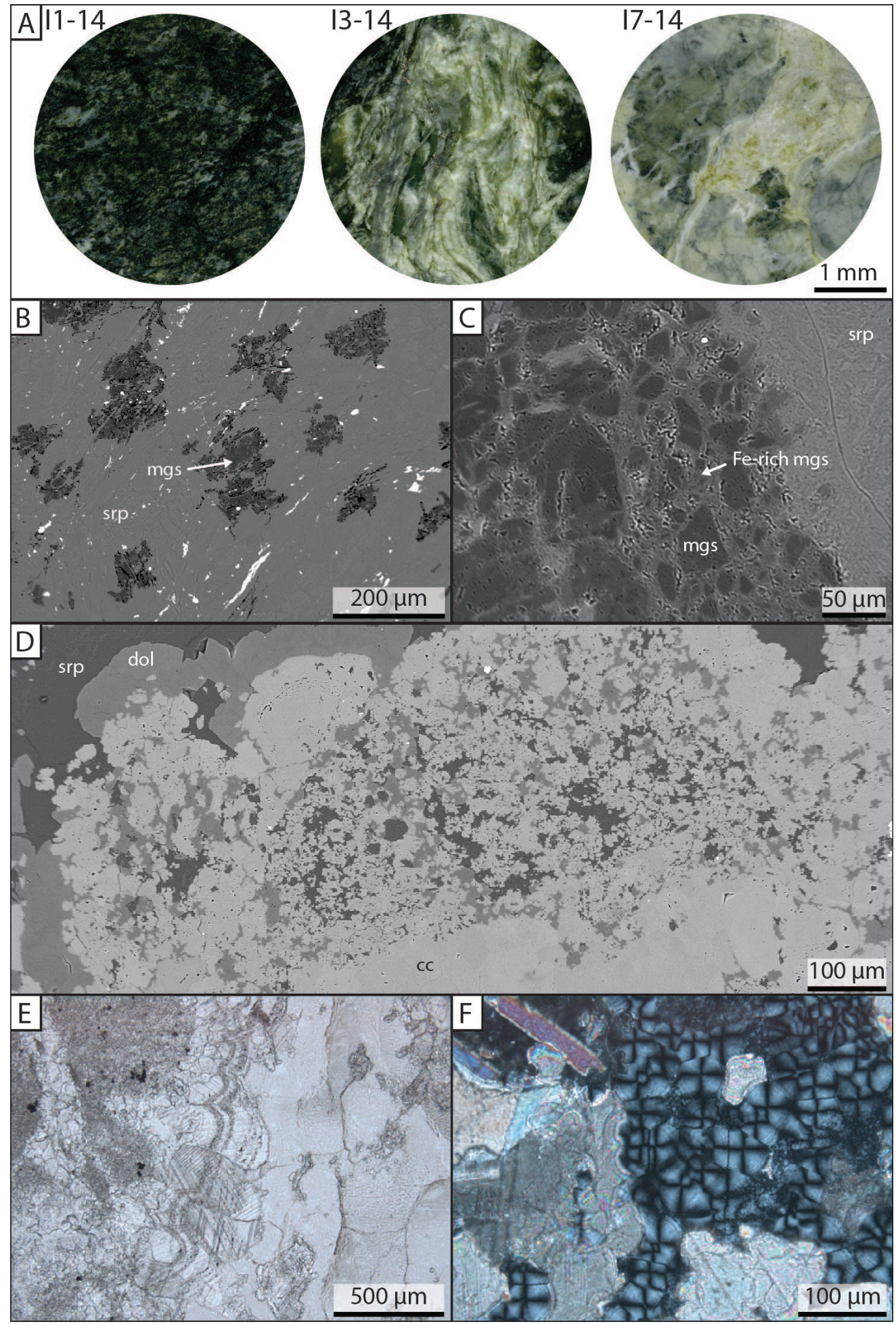

Figure 3. Replacive carbonation NW of Fjelltjønn (outcrop A). (A) Polished surfaces of samples I1-14, I4-14, and I7-14. A mesh texture is visible in the least carbonated sample (I1-14). The more carbonated samples (I3-14 and I7-14) are more deformed. (B) Dendritic magnesite (mgs) in serpentine (srp) (Sample I1-14). (C) Fe-poor magnesite (mgs) surrounded by Fe-rich magnesite (Fe-rich mgs) adjacent to a serpentine area (srp) (Sample I4-14.) (D) Ca-carbonate (cc) of different grain sizes, dolomite (dol) along Ca-carbonate grain boundaries and as overgrowths. Srp - serpentine. (Sample I6-14.) (E) Inclusions in carbonates outlining botryoidal shapes. Plane-polarised light. (Sample I7-14.) (F) Spheroidal serpentine with convex boundaries toward the carbonates. Cross-polarised light. (Sample I7-14.)

In the northernmost part of this outcrop, the rocks consist mainly of massive Ca-carbonate of very variable grain sizes (several $\mu \mathrm{m}$ to several $100 \mu \mathrm{m}$ ). In sample I6-14, dolomite occurs along Ca-carbonate grain boundaries and as overgrowths (Fig. 3D). Fine grain sizes predominate in sample I7-14 and the sparse coarser grains show inclusion trails recording precursory botryoidal textures (Fig. 3E). Small amounts 
of serpentine are present in these samples as well. Relics of interlocking serpentine are cut by carbonates in I6-14. In sample I7-14, serpentine occurs almost exclusively as spheres of polyhedral serpentine with diameters up to 50 $\mu \mathrm{m}$, and commonly with convex boundaries towards the carbonate (Fig. 3F).

\section{Outcrop B: Carbonated serpentinite breccia}

North of lake Fjelltjønna, a serpentinite breccia composed of veined serpentinite clasts in a light-grey carbonate matrix crops out. The amount of matrix is significantly higher than that of the clasts (Fig. 4A). The serpentinite is strongly fragmented, chips have been broken off and the carbonate veins are usually lined with schistose serpentine (Fig. 4B).

The vein carbonates are dominantly Ca-carbonates, and occur in large, macroscopically visible veins between the serpentinite clasts and as smaller veins within the clasts themselves. The veins are sparitic, containing mostly large carbonates with few smaller, cloudy crystals in between (Fig. 4C). Some of the Ca-carbonates contain oriented inclusions of dolomite (Fig. 4D). Many Ca-carbonate crystals are euhedral with hexagonal shapes being common. Some crystals have grown further after the initial euhedral stage, leading to an irregular

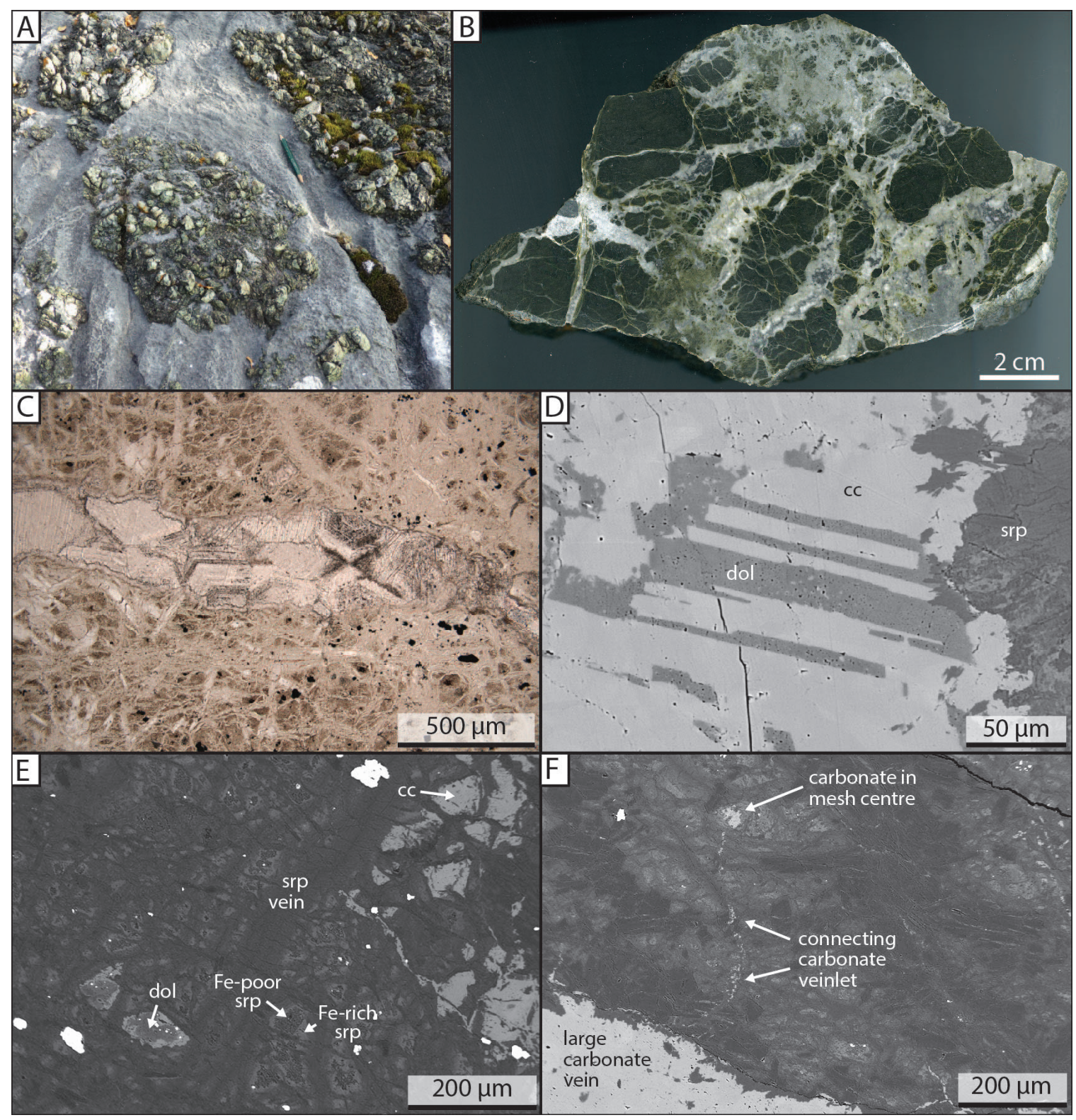

Figure 4. Serpentinite breccia with Ca-carbonate matrix, north of Fjelltjønna (outcrop B). (A) Outcrop surface with green serpentinite clasts surrounded by grey carbonate matrix. Pencil for scale. (B) Polished surface of a hand sample (OC07-14). Serpentinite fragments fit together, showing that the brecciation occurred in situ. (C) Carbonate vein between two serpentinite clasts, plane-polarised light. (Sample OC07-14B.) (D) Oriented dolomite (dol) in Ca-carbonate (cc). Serpentine (srp) on the right. (BSE image, sample OC07-14B.) (E) BSE image of a serpentinite clast. Serpentine (srp) occurs as veins, and as two types of mesh filling (Fe-rich and Fe-poor). The serpentine mesh centre is partly replaced by Ca-carbonate (cc) and dolomite (dol). (Sample OC07-14B.) (F) Thin Ca-carbonate veinlet connecting a Ca-carbonate occurrence in a serpentinite clast to a large Ca-carbonate vein. (BSE image, sample OC07-14B.) 
shape in which the previous euhedral crystal surfaces are outlined by inclusions or pores. Parts of the carbonate veins are filled with serpentine.

Within the serpentinite fragments, carbonates occur as small (c. $50 \mu \mathrm{m})$, polycrystalline grains in the centres of the serpentine mesh (Fig. 4E). The mesh itself is always defined by serpentine, but several variations of the mesh centres have been observed: It can be filled with porous serpentine, whose Fe content is highest between the mesh and the inner part of the filling, or with Ca-carbonate. Seldom, brucite or Ca-carbonate-rimmed dolomite occurs as well. The absolute differences in Fe content of the serpentine could not be determined because of the high porosity of the serpentine.

In some places, small veinlets of Ca-carbonate connect carbonate occurrences in the mesh to the larger veins (Fig. 4F). No evidence for pre-existing clinopyroxene, such as typical alteration minerals or microstructures after clinopyroxene, have been observed in the serpentinite clasts.

Samples OC03-16A and B were taken next to a small shear zone close to the other samples (Table 1). The serpentinite clasts are cross-cut by Ca-carbonate veinlets ( $<30 \mu \mathrm{m}$ width) and slightly larger dolomite veinlets, which intersect the Ca-carbonate ones. Some mesh centres are filled with dolomite, and the matrix phase surrounding the serpentinite clasts is also composed of dolomite.

Outcrop C: Brucite-rich serpentinite breccia

On the slope northeast of Fjelltjønna another type of serpentinite breccia with a white matrix occurs (Fig. $5 \mathrm{~A})$. It crops out locally over a width of approximately 2 $\mathrm{m}$ and is bordered by schistose serpentinite in the east. The western boundary is covered by serpentinite gravel. The serpentinite fragments are comparable to those in OC07-14, but instead of carbonates, brucite is present in the veins (sample OC08-14), which occurs in large fans or rosettes that commonly emanate from vein walls (Fig. 5B). A single brucite crystal can be clear in some parts and extremely inclusion-rich in others (Fig. 5C, D). The inclusion phases are dolomite and magnetite. The dolomite inclusions give the brucite a cloudy brown appearance in light microscopy (Fig. 5B). Brucite crystals that are part of the same fan usually have the same arrangement of inclusions. Magnetite inclusions are generally concentrated at the tips of the brucite crystals.

Outcrop D: Cryptocrystalline magnesite in serpentinite At an outcrop west of Svartberget, white carbonate veins cutting through the serpentinite are weathered to a yellowish colour (Fig. 6A, B). Although the angular serpentinite fragments (Fig. 6B) with small amounts of magnesite in the serpentinite mesh centres are similar to those in the carbonated serpentinite breccias in outcrop

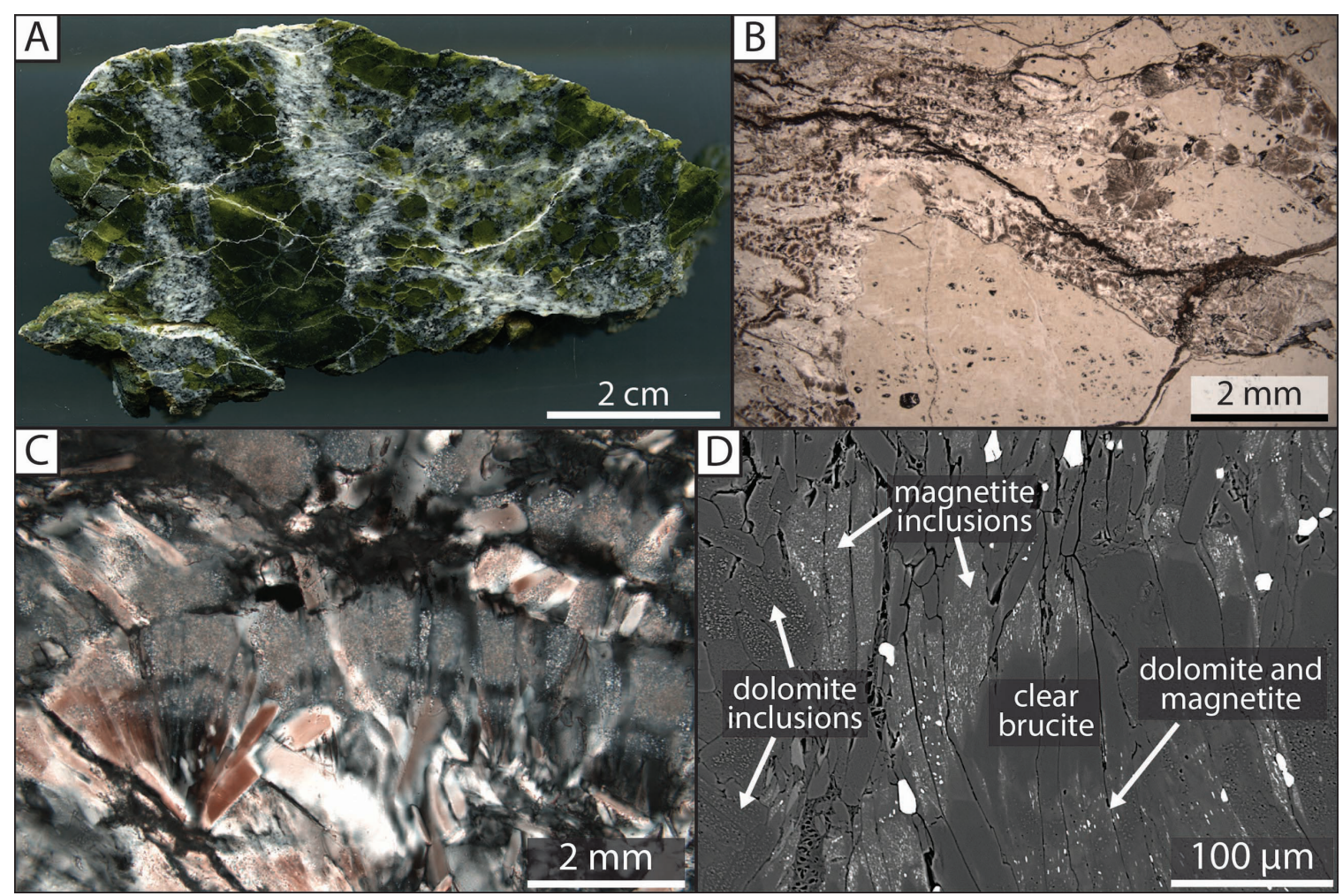

Figure 5. Serpentinite breccia with brucite matrix (outcrop C, sample OC08-14). (A) Polished surface of sample OC08-14. (B) Plane-polarised light micrograph of serpentinite clasts surrounded by brownish brucite. (C) Brucite fans with a constant distribution of inclusions. Cross-polarised light. (D) BSE image of brucite crystals containing magnetite and dolomite inclusions. 


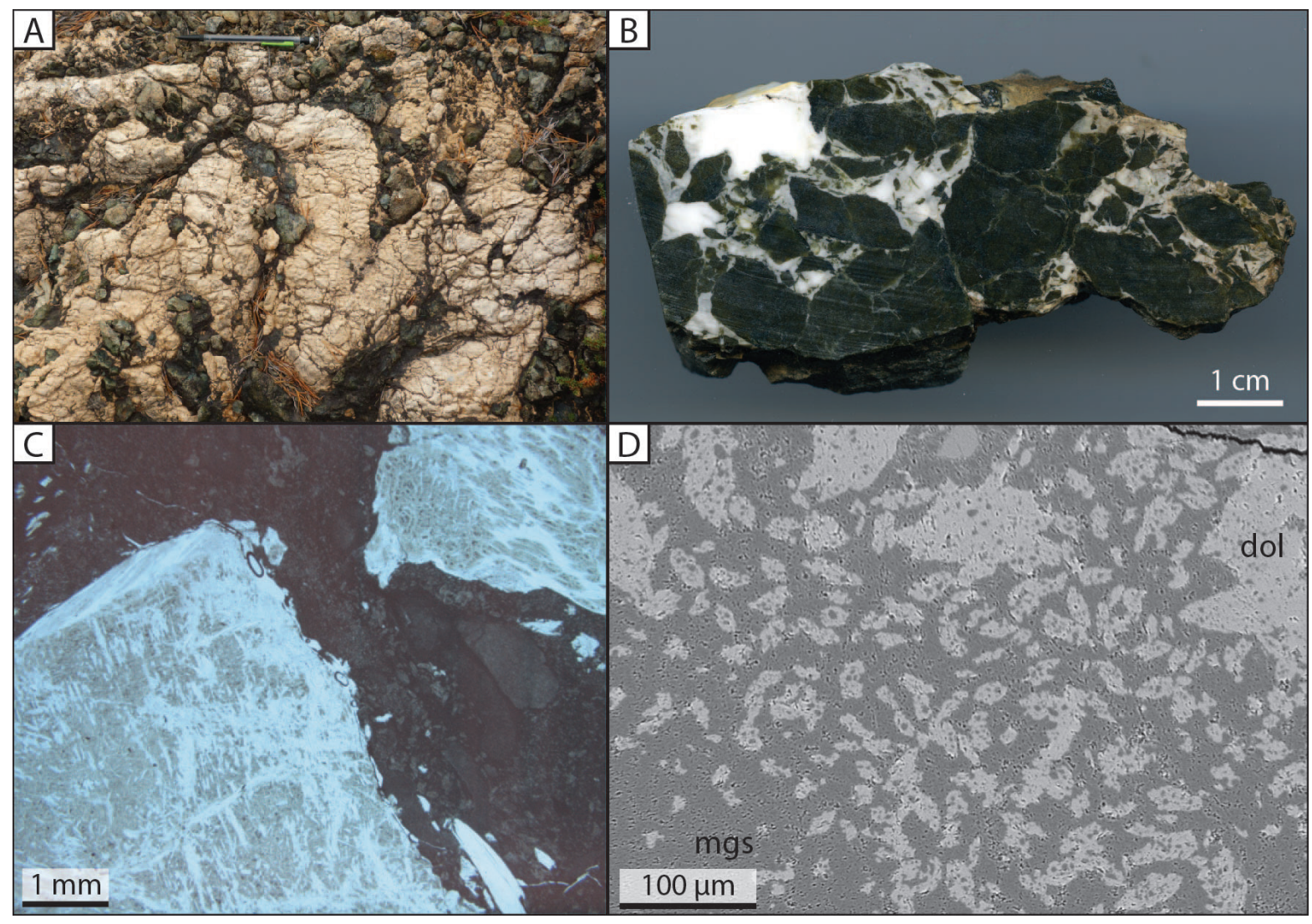

Figure 6. Cryptocrystalline magnesite in serpentinite (outcrop D). (A) Outcrop with green serpentinite clasts in yellow magnesite. Photo courtesy of Manuel Menzel. (B) Polished surface of sample OC02-16, showing green serpentinite fragments and white carbonate matrix. (C) Optical micrograph (plane-polarised light) with two serpentinite fragments and a carbonate matrix. (D) BSE image of the carbonate matrix showing dolomite lenses (dol) in magnesite (mgs).

$B$, there are three differences between those breccias and the ones observed here:

a) There is no hierarchical structure to the carbonate veins/matrix (as in Fig. 4),

b) the carbonate phase is magnesite instead of Cacarbonate, and

c) the carbonate phase is cryptocrystalline.

The veins at outcrop D consist of cryptocrystalline, cloudy magnesite (Fig. 6C), which is cut by sparitic veinlets composed of magnesite (with variable $\mathrm{Fe}$ contents) and dolomite. Dolomite also occurs as lenses in the cryptocrystalline magnesite (Fig. 6D).

In the northern part of the outcrop, a sharp boundary towards the conglomerate (see section F) is exposed. In the southern part, serpentinite with magnesite in the mesh centres occurs, similar to that in outcrop A.

\section{Outcrop E: Dolomitised carbonated serpentinite breccia}

The serpentinite breccia cropping out along the southern edge of Svartberget (Fig. 7A) looks macroscopically similar to the one at outcrop B. However, carbonate occurs as dogtooth cement (Fig. 7B, C), indicating that the matrix used to be much more porous. The carbonate phase constituting the matrix is dolomite, which also occurs in the centres of the serpentinite mesh in the clasts. In sample OC10-14, brucite occurs in the mesh centres in the middle of the serpentinite clasts whereas dolomite occurs in the mesh centres along the edges of the clasts.

The dogtooth dolomite points inward in former pores of different shapes. Most common are hexagons, followed by rectangles and rhombs. Some dolomite also occurs in irregular pores. The dolomite within one pore has a constant extinction orientation, indicating a constant crystallographic orientation. Compositional zonations, with variable $\mathrm{Ca}, \mathrm{Mg}, \mathrm{Fe}$ and $\mathrm{Mn}$ contents, are common (Fig. 7C). Dolomite teeth pointing in the opposite direction surround many of the polygonal pores. Their zonation is not necessarily equal to that of the internal dolomite. Serpentine commonly outlines the polygons.

In places the pores are filled completely, but in most cases serpentine occurs in the centres, either microcrystalline or as polyhedral spheres as described from outcrop A. Serpentine also seems to replace large euhedral carbonate grains of the matrix, occurring as aggregates of fibrous serpentine preserving the cleavage or twin planes of the precursory carbonate (Fig. 7D). 


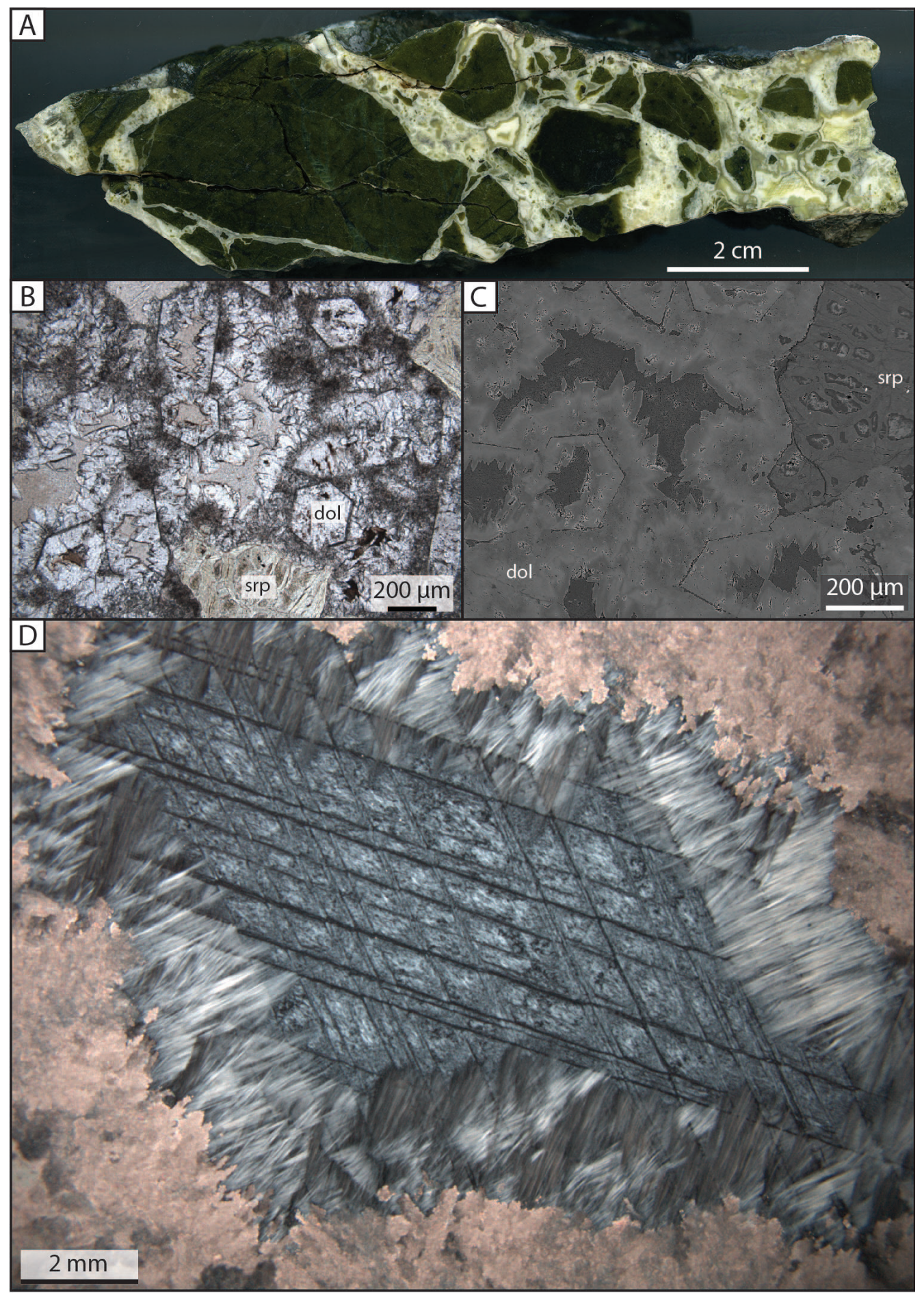

Figure 7. Serpentinite breccia with dolomite matrix (outcrop E). (A) Polished surface of sample OC10-14. (B) Optical micrograph in plane-polarised light showing dolomite (dol) growing inwards from polygonal shapes. Inclusion-rich dolomite has a cloudy brown colour. In the bottom centre and top right are serpentinite clasts (srp). Poorly crystalline serpentine occurs between the dolomite grains. (Sample Rør16-10a.) (C) BSE image of a similar area as that shown in (B). Variable backscatter intensity indicates a compositional zonation in dolomite (dol). Srp - serpentine. (Sample Rør16-10a.) (D) Serpentine pseudomorph after carbonate. Note the rhomboidal shape of the serpentine aggregate and the sharp parallel lines, resembling carbonate twin or cleavage planes. (Sample OC03-14.)

\section{Outcrop F: Conglomerate}

Svartberget consists mainly of a conglomerate, which has been sampled at different parts of the ridge. The conglomerate contains mainly ultramafic clasts with different degrees of serpentinisation. Subordinately, there are clasts of carbonated ultramafic rocks and cryptocrystalline magnesite as described from outcrop $\mathrm{D}$ (Fig. 8). Sorting of the clasts is poor. The matrix is predominantly dolomite and includes small fragments of serpentine. The larger clasts contain a grey core surrounded by a red weathering rind. 


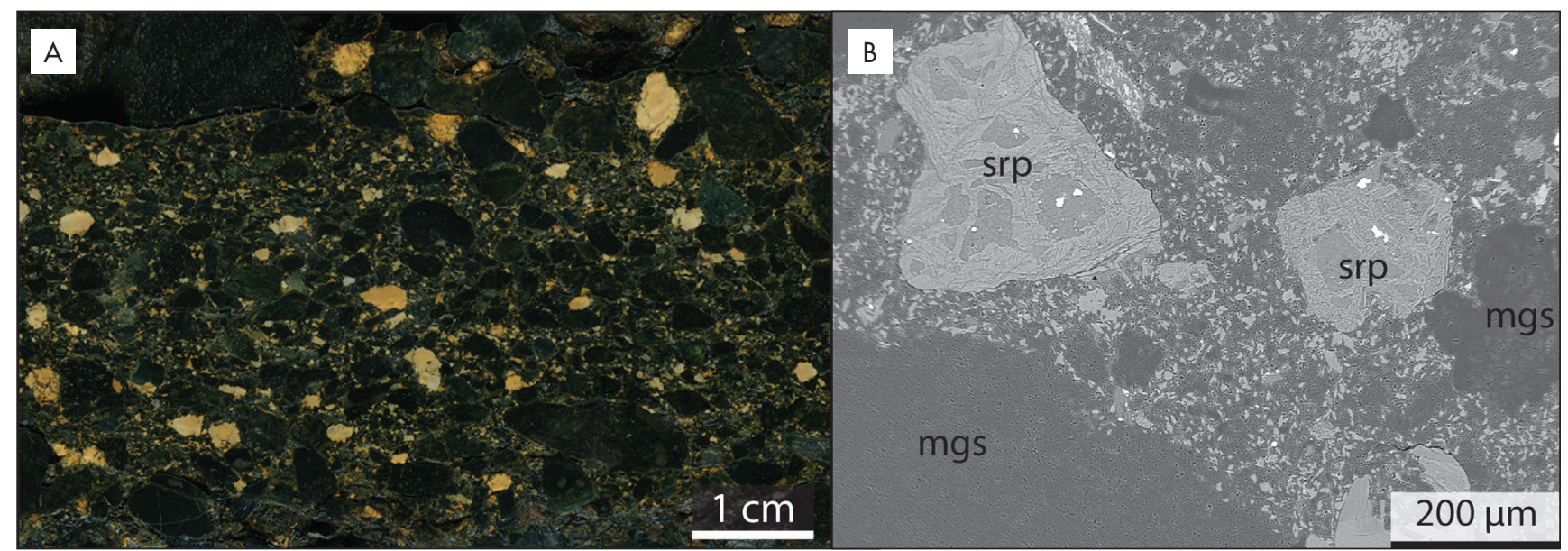

Figure 8. Conglomerate at Svartberget (sample OC02-14). (A) Polished surface with yellow magnesite clasts and dark serpentinite clasts. (B) BSE image with magnesite ( $\mathrm{mgs}$ ) and serpentinite (srp) clasts.

\section{Mineral chemistry}

The compositions of carbonates and silicates are shown in Electronic Supplements 1 \& 2, respectively. The carbonate compositions are summarised in Fig. 9.

Ca-carbonate compositions are very close to the ideal formula of $\mathrm{CaCO}_{3}$. Some dolomite and magnesite analyses include several mole\% $\mathrm{FeCO}_{3}$ and $\mathrm{MnCO}_{3}$. The $\mathrm{FeCO}_{3}$ content of the $\mathrm{Mg}$-carbonates may exceed 10 mole\% (breunnerite). On average, the magnesite in the pervasively altered serpentinites of outcrop (A) contains less $\mathrm{MnCO}_{3}$ than the magnesite of the conglomerates and breccias at Svartberget.

The serpentine in the serpentinite breccias has an average composition of $\mathrm{Mg}_{2.8} \mathrm{Fe}_{0.2} \mathrm{Si}_{2} \mathrm{O}_{5}(\mathrm{OH})_{4}$, but the $\mathrm{Mg} / \mathrm{Fe}$ ratio is variable (with Fe in formula units ranging from 0.1 to 0.5$)$. Talc has similar $\mathrm{Mg} / \mathrm{Fe}$ ratios, with an average formula of $\mathrm{Mg}_{2.9} \mathrm{Fe}_{0.1} \mathrm{Si}_{4} \mathrm{O}_{10}(\mathrm{OH})_{2}$.

\section{Oxygen and carbon isotope compositions}

Carbon and oxygen isotopic compositions have been acquired from 22 samples from outcrops A, B, D, E and $\mathrm{F}$. There are two distinct $\delta^{18} \mathrm{O}$ populations (Fig. 10): The pervasively carbonated serpentinites (outcrop A) and serpentinite breccias (B) from Fjelltjønna and the ultramafic clasts from the conglomerate $(\mathrm{F})$ and the dolomitised carbonated serpentinite breccia have a mean $\delta^{18} \mathrm{O}$ of $12.6 \%$ ( $\mathrm{SD}: 0.6 \%$ ); the conglomerate matrix (F) has a mean $\delta^{18} \mathrm{O}$ of $23.9 \%$ (SD: $2.0 \%$ ). Dolomite-rich samples from outcrops A and E (OC0316 and OC03-14) record a $\delta^{18} \mathrm{O}$ of $20.6 \%$ (SD: $0.3 \%$ ), and the cryptocrystalline magnesite samples $26.0 \%$ (SD: $0.9 \%)$.

The carbon isotope data do not show a clear dependence on lithology. Values range from $-7.5 \%$ to $0.6 \%$.
Repeated analysis of seven samples shows high standard deviations (up to $0.74 \%$ for $\delta^{18} \mathrm{O}$ and $0.72 \%$ of $\delta^{13} \mathrm{C}$ ), indicating heterogeneous sample compositions, which were probably caused by a mixing of clasts and matrix. See Table 2 for details.

\section{Discussion}

\section{Settings of carbonation in the FUB}

The carbonation of the FUB may have taken place at the ocean floor or in the lacustrine Devonian basin. The ultramafic clasts in the conglomerates of the Devonian Solund basin (Beinlich et al., 2010) developed to red carbonate-quartz-hematite-rich clasts identical to the red clasts found in the polymict conglomerate of the Røragen basin (Beinlich et al., 2018). According to Beinlich et al. (2010), the carbonation of weathered ultramafic material took place within the basin (Beinlich et al., 2010). We suspect a similar origin for the red clasts of the Røragen basin.

The investigated samples can be grouped into pervasively carbonated serpentinites (outcrop A and southern part of outcrop D), serpentinite breccias with Ca-carbonates (outcrop B), brucite (C), or dolomite (E) as the main matrix phase, serpentinite breccias with veins of cryptocrystalline magnesite (D) and carbonate-cemented conglomerates (outcrops F). As the contact between the serpentinites and the serpentinite breccias is not well exposed and the contact between the breccias and the conglomerate is clearly discordant, the geological settings of the various carbonation events cannot be determined in detail. The presence of carbonated serpentinite clasts and magnesite clasts in the conglomerate, which have the same oxygen isotope composition as the carbonated serpentinite breccias, indicate that the conglomerate formed after the carbonation of the upper part of the 
A

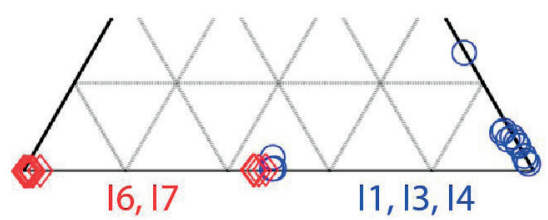

C

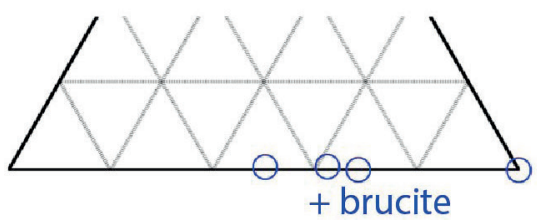

$\mathrm{E}$

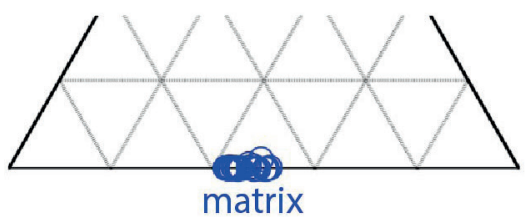

B

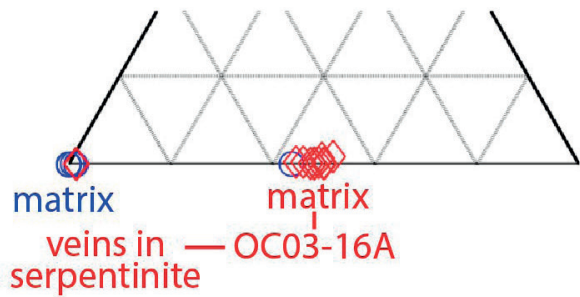

D

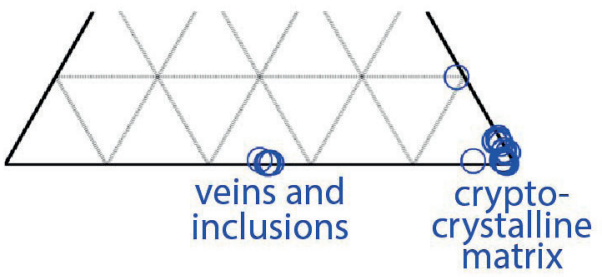

$F, F^{\prime}$

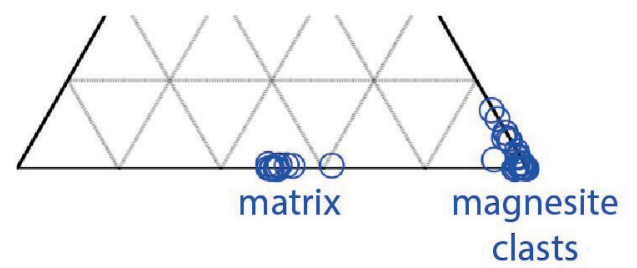

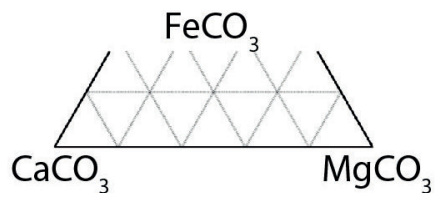

Figure 9. Carbonate compositions in mole\% fraction from the six outcrops illustrating the variable alteration types in the FUB. The matrix of the serpentinite breccia from outcrop C contains mainly brucite and only small amounts of carbonate. The apparently magnesium-rich dolomite here may be the result of a mixed analysis.

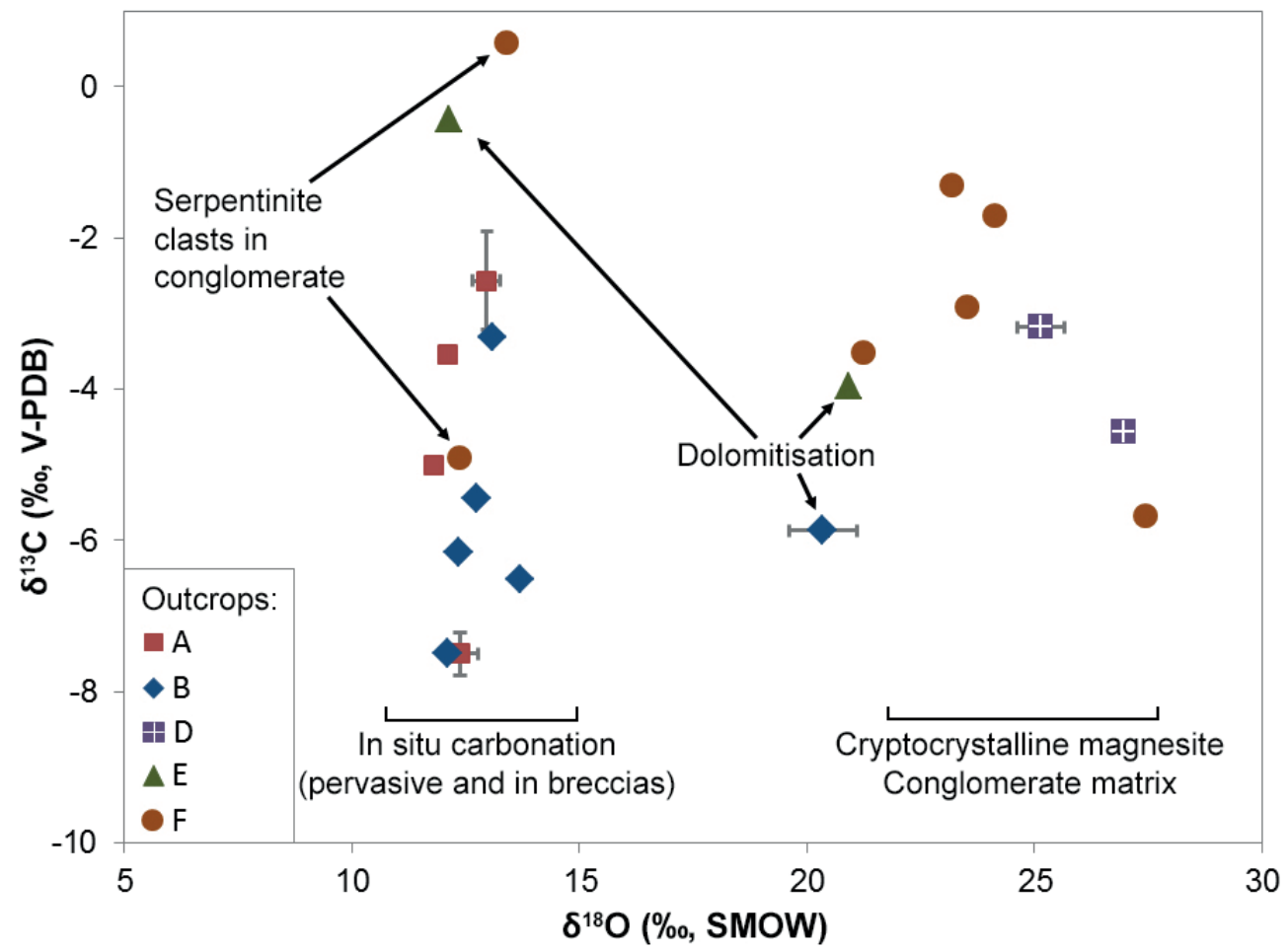

Figure 10. Isotope data showing two distinct populations in $\delta 180$. The low $\delta 180$ ratios of two conglomerate samples show that the tectonic ophicarbonates were reworked and incorporated in the conglomerate. The error bars give the standard deviation of samples with repeated analyses 
Table 2. Oxygen and carbon isotope compositions of ophicarbonate samples. Bn - breunnerite, Ca-C - calcium carbonate, Dol - dolomite, Mgs - magnesite. (Samples I7-14_A and I7-14_B are subsamples of I7-14.)

\begin{tabular}{|c|c|c|c|c|c|c|c|}
\hline \multirow{3}{*}{$\begin{array}{c}\text { Sample } \\
\mathrm{I} 1-14\end{array}$} & \multirow{3}{*}{$\begin{array}{c}\text { Outcrop } \\
\text { A }\end{array}$} & \multirow{3}{*}{$\begin{array}{c}\begin{array}{c}\text { Carbonate } \\
\text { phase }\end{array} \\
\text { Mgs, Dol }\end{array}$} & $\delta^{18} \mathrm{O}$ & $S D$ & $\delta^{13} C$ & $S D$ & \multirow{3}{*}{$\begin{array}{c}\begin{array}{r}\text { Number of } \\
\text { replicates }\end{array} \\
5\end{array}$} \\
\hline & & & \multicolumn{2}{|c|}{$(\%$, SMOW $)$} & \multicolumn{2}{|c|}{$(\% o, V-P D B)$} & \\
\hline & & & 13.0 & 0.30 & -2.6 & 0.65 & \\
\hline I3-14 & A & Mgs, Dol, Bn & 12.4 & 0.38 & -7.5 & 0.28 & 5 \\
\hline I7-14_A & A & $\mathrm{Ca}-\mathrm{C}$ & 11.8 & & -5.0 & & 1 \\
\hline I7-14_B & A & $\mathrm{Ca}-\mathrm{C}$ & 12.1 & & -3.5 & & 1 \\
\hline OC05-14 & B & $\mathrm{Ca}-\mathrm{C}$ & 12.7 & & -5.4 & & 1 \\
\hline OC06-14 & B & $\mathrm{Ca}-\mathrm{C}$ & 12.1 & & -7.5 & & 1 \\
\hline OC07-14 & B & $\mathrm{Ca}-\mathrm{C}$ & 12.3 & & -6.2 & & 1 \\
\hline OC03-16 & B & Ca-C, Dol & 20.4 & 0.74 & -5.9 & 0.09 & 2 \\
\hline RØR02a & $\mathrm{B}^{\prime}$ & unknown & 13.1 & & -3.3 & & 1 \\
\hline $\mathrm{R} \emptyset \mathrm{R} 02 \mathrm{~b}$ & $\mathrm{~B}^{\prime}$ & unknown & 13.7 & & -6.5 & & 1 \\
\hline OC02-16 & $\mathrm{D}$ & Mgs, Dol, Bn & 25.1 & 0.52 & -3.2 & 0.09 & 2 \\
\hline OC09-14 & $\mathrm{D}$ & Mgs, Dol & 27.0 & 0.23 & -4.6 & 0.08 & 4 \\
\hline OC03-14 & $\mathrm{E}$ & Dol & 20.9 & 0.35 & -4.0 & 0.10 & 2 \\
\hline OC10-14 & $\mathrm{E}$ & Dol & 12.1 & 0.23 & -0.4 & 0.72 & 3 \\
\hline OC02-14 & $\mathrm{F}$ & Mgs, Dol & 27.4 & & -5.7 & & 1 \\
\hline RØR09 & $F^{\prime}$ & unknown & 23.5 & & -2.9 & & 1 \\
\hline RØR10/07 & $\mathrm{F}^{\prime}$ & Mgs, Dol & 21.2 & & -3.5 & & 1 \\
\hline RØR11/07 & $F^{\prime}$ & Mgs, Dol & 23.2 & & -1.3 & & 1 \\
\hline $\mathrm{R} \varnothing \mathrm{R} 12 / 07$ & $\mathrm{~F}^{\prime}$ & Mgs, Dol & 13.4 & & 0.6 & & 1 \\
\hline RØR13/07 & $F^{\prime}$ & Mgs, Dol & 24.1 & & -1.7 & & 1 \\
\hline RØR16/07 & $F^{\prime}$ & Mgs, Bn & 12.4 & & -4.9 & & 1 \\
\hline
\end{tabular}

FUB. The grading from the monomict to the polymict conglomerate suggests that the catchment area increased, possibly due to continued extension.

Oxygen isotope compositions record two distinct carbonation events for the ultramafic rocks and the conglomerates. The Ca-carbonate-bearing serpentinite breccias, the pervasively carbonated serpentinites and the clasts of carbonated serpentinites in the conglomerate have significantly lower $\delta^{18} \mathrm{O}$ values $(12.6 \%$ ) than the conglomerate samples with high matrix contents $(23.9 \%)$ and the magnesite-bearing serpentinite breccia $(26.0 \%)$. This suggests lower carbonate crystallisation temperatures for the first group than for the rest. Another possibility is that all carbonates formed at the same time, with the oxygen isotope composition of those in the first group being lowered through re-equilibration of the carbonate with the serpentine. However, this is unlikely as the amount of carbonate in the serpentinite breccias is generally as high or higher as in the conglomerate (compare Figs. 4A \& 8A).
The serpentinite breccias contain closely fitting, angular serpentinite clasts (Figs. 4B \& 5B), are monomict and show no sorting of the clasts. This means that movement of the clasts was minimal and the breccia was formed in situ. In places, this in situ fracturing, alteration and cementation was substantial, as shown by the large amounts of carbonate surrounding the carbonate-veined serpentinite clasts in outcrop B, for example (Fig. 4A). In other ophicarbonate outcrops, rocks with such high carbonate to serpentinite clast ratios contain sedimentary structures (e.g., Totalp unit; Bernoulli \& Weissert, 1985), but this is not the case here. Reaction-induced fracturing likely contributed to the deformation and alteration of the serpentinites. The increase in the volume of solids during the carbonation reaction (e.g., (Marini, 2007, p. 164) leads to fracturing, similar to the volume increase during serpentinisation, for which the resulting reaction-induced fracturing has been described by e.g., Iyer et al. (2008) and Jamtveit \& Hammer (2012). The hierarchical fracture pattern observed particularly in outcrop B (Fig. 4B) supports the involvement of reaction-induced fracturing. 
Apart from the brittle brecciation, the serpentinite breccias show no evidence for deformation such as shear zones or deformation twins in the carbonates, which is in contrast to the ophicarbonates from the Totalp unit or the Iberian margin (Comas et al., 1996; Picazo et al., 2013), for example. Because small serpentine fragments in the carbonate or brucite veins are rare, grinding or milling was minimal. Possibly, decompression fractures related to the exhumation of the mantle rocks were sufficient to start the carbonation reaction. The volume increase associated with this reaction then caused further fracturing as described above. The fluid pathways used during serpentinisation have not been reactivated during carbonation, as the carbonate does not follow serpentine veins but cuts across them.

Large, faceted crystals (Fig. 4C) and relics of botryoidal textures (Fig. 3E) show that not only replacement, but also growth in open fractures took place. The abundance and width of these veins indicates that fracturing had a dilational component and that carbonation took place at low confining pressure. That the carbonation of ultramafic rocks in an oceanic setting is limited to the uppermost part of the exhumed mantle, at or near the seafloor, has been described before, for example from the Totalp unit (upper 20 m; Picazo et al., 2013) and the Iberian Margin (upper 30-60 m; Alt \& Shanks, 1998). Whether the serpentinite breccias in Feragen were carbonated in such an oceanic setting or on land is unknown.

\section{The source of carbon}

Carbon isotope data can potentially provide evidence as to the nature of the carbonating fluids. However, there are no groups in the carbon isotope ratios of the investigated samples. Values range from -7.5 to $+0.6 \%$ o $(\mathrm{V}-\mathrm{PDB})$, which is below those of Devonian (the conglomerate overlying the FUB is Devonian) marine carbonates, which have average values between 0.7 and $3.1 \%$ o (Veizer et al., 1999). Similar ranges have been reported from various hydrothermal ophicalcites, for example from Newfoundland (Menzel et al., 2018), the Pyrenees, the Alps and the Apennines (see (Clerc et al., 2014) for a compilation of carbon and oxygen stable isotope data). Detailed discussions on potential sources of ${ }^{13} \mathrm{C}$-depleted carbon in carbonated ultramafic rocks, such as mantlederived carbon, methane, organic carbon in serpentinites and carbon-bearing meteoric waters are provided by, among others, Schwarzenbach et al. (2016) and Menzel et al. (2018). Because our knowledge of the geological setting of the FUB at the time of carbonation is limited, we cannot determine the source of carbon here.

To calculate crystallisation temperatures from the oxygen isotope compositions of the carbonate minerals, the oxygen isotope composition for the mineralising fluid and the mineralogy of the carbonate need to be known.
Because the $\delta^{13} \mathrm{C}$ values of the investigated samples do not allow for the exact determination of the fluid source, and because the exact ratio of the carbonate phases in the particular subsamples used for the isotopic analyses are unknown, temperature estimates would be very uncertain and are therefore not presented.

\section{Fluid pathways}

The extent of replacive calcium-carbonate formation in outcrop B shows that there must have been significant transport of ions in solution, as both calcium and carbonate ions had to be introduced into the rock, while magnesium and silicon had to be removed. In open fractures, this scale of transport is easily conceivable, but how the transport to and from the inside of the serpentine mesh was provided is not obvious. Some mesh centres are connected to large carbonate veins by small veinlets, but this is not ubiquitous. Therefore, diffusion through porous serpentine, without the formation of fractures, has been sufficient for smallscale carbonation, but was slow enough that only the outer parts of some serpentinite clasts were carbonated. In some serpentinite clasts, there is a zonation in the mineralogy of the serpentine mesh centre, with brucite in the centre of the clast and dolomite in the rim, towards the dolomite veins. This shows that the transport of fluid through the serpentinite was limited and that the composition of the serpentinite clasts depended not only on pressure, temperature, and fluid composition, but also on fluid availability, and illustrates the importance of fractures for progress of the reaction. Similarly, during experimental carbonation of partially serpentinised peridotites, reaction with a $\mathrm{Na}-\mathrm{Ca}-\mathrm{Cl}$ solution produced mainly calcite, but magnesite grew in the inner parts of the sample, suggesting that transport through the sample was limited and that the local fluid composition differed from that of the bulk fluid (Hövelmann et al., 2011).

\section{Pervasive carbonation}

Pervasive carbonation is most prominent at outcrop A, where soapstones, consisting of magnesite and talc, and rocks consisting of almost pure Ca-carbonate occur. However, also in other outcrops, there was minor replacement of serpentine in the mesh centres by different carbonate minerals. Whereas the formation of soapstone is a typical result of $\mathrm{CO}_{2}$-metasomatism of serpentinites, the replacement of serpentine by carbonates, without associated quartz or talc, presents a mass balance problem, as it implies a net loss of silicate. The sink for the excess silicate is unknown in this case. Possibly, a silica-rich crust formed above the ultramafic rocks (Oskierski et al., 2013) and was later eroded.

The samples taken at outcrop A show strong variation in microstructures and compositions indicating differences 
in the mode of deformation and the composition of the reactive fluid. The partly carbonated serpentinites have a mostly undeformed serpentine mesh texture with sparse serpentine microshearzones, whereas the soapstones are strongly foliated (Fig. 3A). Deformation likely aided the transport of reactive fluids into the rocks. In the northern part of the outcrop, brittle deformation also played a role, and led to the growth of carbonates in open fractures, as recorded by the coarse-grained carbonates with inclusion trails preserving the shape of pre-existing botryoids (Fig. 3E).

Fluid conditions have varied spatially and temporally, even within this limited outcrop, as evidenced by the different types and compositions of the carbonates and silicates:

- While the more southern samples (I1-14, I3-14, I4-14) are dominated by magnesite, the northern samples (I6-14 an I7-14) contain mainly Ca-carbonate. Possibly, not only the extent but also the type of carbonation was determined by the degree of deformation. In the more deformed samples, fluid circulation was easier and therefore Ca more available. In the less deformed samples, the composition of the fluid was probably dominated by the dissolution of serpentine, which liberates $\mathrm{Mg}$.

- The variation in the $\mathrm{Fe}$ content of magnesite in samples I3-14 and I4-14 (Fig. 3C) points to the alteration of an original Fe-poor magnesite to a more Fe-rich magnesium carbonate. Possibly, this is related to the breakdown of magnetite or a change in redox conditions of the fluid.

- Sample I6-14 contains both dolomite and Ca-carbonate. Dolomite, which is less abundant, occurs along Ca-carbonate grain boundaries and as overgrowths. This is possibly an incomplete dolomitisation, indicating an influx of $\mathrm{Mg}$-rich fluids. Dolomitisation was likely a late-stage event, with late faults and fractures allowing for the local fluid infiltration. This has also been observed at other outcrops (B and E).

- The dissolution of carbonates and precipitation of serpentine (Fig. $3 \mathrm{~F}$ ) shows that after the carbonating event, serpentine became stable again, probably due to a shift in $\mathrm{CO}_{2}$ partial pressure. Secondary serpentine has also been observed in the matrix of breccias of other ophicarbonate outcrops (Boillot \& Froitzheim, 2001). Polyhedral serpentine spheres, as occur here, have been attributed to crystallisation from a gel-like precursor phase via an intermediate stage of protoserpentine, and form in open spaces at temperatures below $200-300^{\circ} \mathrm{C}$ (Andreani et al., 2008).

\section{Carbonation and alteration of serpentinite breccias}

Serpentinite breccias are described from four outcrops, and while their macroscopic appearance is similar, the amount, microstructure and mineralogy of the matrix phase differ.

\section{Ca-carbonate veins in serpentinite breccia}

The serpentinite breccia at outcrop B has a Ca-carbonate matrix. As the serpentinite clasts do not contain evidence for pre-existing clinopyroxene, which would have been a potential calcium source, significant mass transport must have occurred. Not only the carbon, but also the calcium had an external source, such as seawater or fluids that serpentinised lower units of the FUB, which contain clinopyroxene-bearing peridotite. During the interaction of the fluids with that peridotite, they would have become progressively richer in $\mathrm{Ca}^{2+}$ and formed calcium carbonates when they rose sufficiently to encounter seawater (Barnes et al., 1978; Palandri \& Reed, 2004) or atmospheric $\mathrm{CO}_{2}$ (Neal \& Stanger, 1985; Mervine et al., 2014).

The hexagonal shape preserved in some of the largegrained carbonate veins suggests that aragonite was the first mineral to precipitate in these veins. Aragonite was also found in veins and cavities in serpentinised peridotites from, for example, the Romanche and Vema Fracture Zones and the Owen Fracture Zone (Bonatti et al., 1980), from the Atlantis Massif (Eickmann et al., 2009) and from the Iberia Abyssal Plain (Morgan \& Milliken, 1996). The initial precipitation of aragonite is consistent with temperatures above $5^{\circ} \mathrm{C}$, at which the growth of metastable aragonite is kinetically favoured (Burton \& Walter, 1987). Other possible reasons for aragonite being precipitated instead of calcite are high strontium or magnesium contents of the fluid. The presence of strontium changes the surface energy during $\mathrm{CaCO}_{3}$ nucleation and favours aragonite precipitation (Sunagawa et al., 2007). Magnesium ions, which are surrounded by a strong hydration shell, are preferentially adsorbed on calcite over aragonite surfaces, and kinetically hinder calcite precipitation (Mucci \& Morse, 1983; Morse et al., 2007). A high magnesium content may have been caused by the dissolution of serpentine. The botryoidal calcium carbonate might represent a replacement of fibrous aragonite or high-Mg calcite by low-Mg calcite (Ross, 1991). The presence of oriented dolomite inclusions supports high-Mg calcite as the precursor.

\section{Brucite veins in serpentinite breccia}

The serpentinite breccias at outcrop $\mathrm{C}$ contain brucite instead of carbonates, which is striking because their microstructure looks identical to that of the carbonatecemented serpentinite breccias at outcrop B, which lies at a distance of less than $200 \mathrm{~m}$. Apparently, there were strong local variations either in the fluid sources or in the amount of fluid that penetrated the serpentinites.

The large brucite fans observed in the serpentinite breccias at outcrop $\mathrm{C}$ have formed in different growth 
episodes, recorded by the distribution of magnetite and dolomite inclusions (Fig. 5C, D). The inclusions are concentrated in bands parallel to the outline of the brucite fans, and many brucite fans show the same succession of inclusions. Because of this, the inclusions do not represent remnants of larger minerals that were replaced by brucite, but signify changes in fluid conditions.

The dolomite inclusions probably reflect small fluctuations in the partial pressure of $\mathrm{CO}_{2}$, caused either by changes in carbonate supply or by subtle pressure (or temperature) variations. That the inclusions are of dolomite instead of magnesite seems to indicate that not only the concentration of $\mathrm{CO}_{2}$ changed when dolomite instead of brucite became stable, but also the $\mathrm{Mg} / \mathrm{Ca}$ ratio of the fluid. However, that does not have to be the case; Ca-hydroxides (portlandite) are very rare in nature (Neal \& Stanger, 1984; Marini, 2007, p. 90) and brucite is stable over a wide range of $\mathrm{Ca} / \mathrm{Mg}$ ratios (Marini, 2007, fig. 5.7-5.9). The dolomite inclusions may also represent temporary decreases in the fluid discharge rate, and thus in the ratio of seawater to hydrothermal fluid, which can shift equilibrium to the carbonate phase (Palandri \& Reed, 2004). Dolomite does not usually form directly from a fluid, but it is unlikely that it replaced magnesite or calcite in this case. If dolomite had been stable for a long enough time to allow for dolomitisation, some recrystallisation that would have increased the small grain size of the inclusions would have been expected as well. It is also questionable as to how dolomitisation could have occurred without changes to the host brucite. Therefore, Ca-Mg-carbonate probably precipitated directly, maybe in the form of protodolomite.

The iron source for the magnetite inclusions is not clear. That the magnetite inclusions are usually concentrated at the tips of the brucite crystals does not necessarily indicate that they formed last, but the growing brucite might also have pushed them in front of itself. In this case, they could be remnants of the serpentinite; the serpentine dissolved, while magnetite remained stable and was incorporated into the brucite.

\section{Formation of cryptocrystalline magnesite}

The magnesite-cemented serpentinite breccias at outcrop $\mathrm{D}$ are significantly different from those at outcrops B and $\mathrm{C}$ (with Ca-carbonate and brucite as the matrix phase). Firstly, they have a more chaotic macroscopic appearance, without a hierarchical pattern. Secondly, they are cryptocrystalline, as opposed to the coarser-grained Ca-carbonates at outcrop B and the large brucite fans at outcrop C. Thirdly, their $\delta^{18} \mathrm{O}$ values are significantly higher than those of the in situ carbonated rocks, similar to those of the conglomerates. Hence, they probably formed later than the other carbonated serpentinite breccias at cooler temperatures.
The magnesite occurring here can be classified as a small Kraubath-type magnesite deposit, a cryptocrystalline magnesite deposit occurring in an ultramafic rock. Typical features of Kraubath-type magnesite deposits such as their white colour, conchoidal fracture, ptygmatic folding of thin veinlets, 'cauliflower' texture and the occurrence of coarser dolomite grains in magnesite (Pohl, 1990), are present here. Kraubath-type deposits are generally interpreted as either concretions in soil or sediments adjacent to, or veins or stockworks within ultramafic rocks (Schroll, 2002). The magnesite precipitates from meteoric water at or near surface temperature, or from hydrothermal fluids at slightly higher temperatures and depths (Schroll, 2002).

Carbon isotopic compositions of cryptocrystalline magnesites in continental ultramafic bodies range globally from $-21 \%$ to $-4 \%$ (del Real et al., 2016; Schwarzenbach et al., 2016, see references therein). These values have been attributed to decarboxylation of organic matter from sediments underthrust beneath an ultramafic body (Fallick et al., 1991; Schwarzenbach et al., 2016) or of adjacent organic-rich sediments (Zedef et al., 2000). The samples from Feragen are at the upper end of this range (-3.2\%o and $-4.6 \% \mathrm{~V}-\mathrm{PDB})$, which might indicate that the influence of organic carbon was relatively small. Worldwide, $\delta 18 \mathrm{O}$ values of cryptocrystalline, Kraubath-type magnesite vary between c. 23 and 34\%o (del Real et al., 2016). The Feragen samples fall within that range. Their relatively low oxygen isotope values $(26.0 \%)$ indicate a hydrothermal rather than a supergene origin of the magnesite.

\section{Carbonation of the conglomerates}

In contrast to the in situ carbonation described above, the conglomerates formed in association with the circulation of synsedimentary fluids. The lack of sorting or bedding indicates a rapid deposition. Such sedimentary ophicarbonates have been described from the Pyrenees, for example (Clerc et al., 2014), and the reworking of carbonated serpentinites and their deposition in overlying breccias, sediments and flysch have been observed in the Totalp ophicarbonates (FrühGreen et al., 1990).

The discordant layering of the conglomerates on top of the carbonated serpentinite breccias is further evidence that two different processes are responsible for the carbonation of the serpentinite breccias and the conglomerates. We therefore suggest that the partly carbonated ultramafic conglomerate at Røragen is a product of reworking of the upper parts of the FUB, leading to the mixing of ultramafic rocks with different degrees of both serpentinisation and carbonation, and cementation by carbonates in a shallow-water setting. 


\section{Dolomitisation}

Dolomite is observed in several rock types in the FUB: a) associated with a shear zone in the serpentinite breccias of outcrop B, b) as the matrix phase in serpentinite breccias of outcrop E, and c) as the matrix of the conglomerate $(\mathrm{F})$.

a) Samples OC03-16A and B record a localised dolomitisation related to deformation of the Ca-carbonate-cemented serpentinite breccia. The Ca-carbonate veining, which, according to the crosscutting relationships, occurred prior to the dolomite, is comparable to that observed in the other samples from this outcrop.

b) The dolomite in the serpentinite breccias at outcrop E commonly forms hollow crystals. They have not formed by dissolution, because the crystal faces are smooth, nor by skeletal growth, because the shape of the inner hole is not parallel to the outer shape. Instead, they are cast pseudomorphs, formed by encrustation, dissolution and filling. This process has been described by Searl (1992) who explained the optical continuity of dolomite with syntaxial growth.

The predominance of hexagonal shapes of the casts suggests that the dissolved phase was aragonite. Another indication for a Ca-carbonate precursor is the composition of the dolomite. The $\mathrm{MgCO}_{3}$ component is as low as $43 \%$.

Low-Mg dolomite has been observed during the initial stages of dolomitisation of calcite (Kaczmarek \& Sibley, 2011). Where a zonation is observed in the dolomite crystals in the dolomite-bearing serpentinite breccias, the lowest $\mathrm{MgCO}_{3}$ contents are in the inner parts, which were presumably most influenced by the Ca-carbonate dissolution.

These dolomite-rich serpentinite breccias only occur in a limited area. The dolomitisation may have been related to a fault, allowing fluids to penetrate the rocks preferentially there. The flat, at places smooth southern wall of Svartberget might be the exposed fault plane.

The isotopic compositions of these dolomite-bearing serpentinite breccias vary significantly, with one of the samples having similar $\delta^{18} \mathrm{O}$ values to the in situ carbonated rocks. Why the oxygen isotope ratio was not reset during the dolomitisation is unclear.

As in several of the lithologies described above, the serpentinite breccias with dolomite matrix have experienced changing fluid conditions. The rhomboidal serpentine aggregates (Fig. 7D) indicate a replacement of carbonate single crystals by serpentine. The preservation of the cleavage shows that dissolution of carbonate and precipitation of serpentine were closely coupled. This preservation would not have been possible if the whole carbonate crystal was dissolved before serpentine grew. Exactly how these unusual microstructures formed is unclear, especially because the rhomboidal serpentine aggregates are surrounded by fine-grained carbonates. However, they clearly record changing fluid conditions and small-scale disequilibrium.

c) The conglomerate matrix consists of dolomite. As dolomite is not known to precipitate directly from seawater (Sibley et al., 1987), it probably replaced another carbonate phase, possibly at the same time as the local dolomitisation at the other outcrops. A dolomitisation event following the initial diagenesis of the conglomerates also explains the average $\delta^{18} \mathrm{O}$ values for the conglomerate matrix of $23.9 \%$, which is lower than expected for a sedimentary process.

\section{Conclusions}

Based on petrographic and geochemical investigations of the ophicarbonates of the FUB, this is a possible succession of events affecting the northern part of the ultramafic body:

- Serpentinisation of the peridotites.

- Obduction of the ultramafic body.

- Initial fracturing of the serpentinites by decompression or tectonic movement.

- Fracture-filling by Ca-carbonate and replacive carbonation of the serpentinite breccia, and further reaction-induced fracturing (either on land or in a shallow-marine setting).

- Extensional orogenic collapse with formation of the Devonian conglomerate

- (Ca-)carbonate cementation of the ultramafic conglomerate.

- Dolomitisation of the carbonated serpentinite breccia and the conglomerate.

Three local events that have unclear timing are the deformation-related formation of soapstone and carbonate rock from serpentinite at outcrop A, the growth of large brucite fans in the serpentinite breccias at outcrop $\mathrm{C}$, and the formation of cryptocrystalline magnesite at outcrop D.

The ophicarbonates of the FUB are unique in that they show extreme variability over a spatial extent of less than $2 \mathrm{~km}$. This shows that hydrothermal systems are not only determined by their tectonic context, but are strongly influenced by small-scale deformation, which can influence the extent and, by its impact on fluid-rock interaction and hence fluid composition, also the type of alteration. 
Acknowledgements. This project has been supported by the People Programme (Marie Curie Actions) of the European Union's Seventh Framework Programme FP7/2007-2013/ under REA-Grant Agreement $\mathrm{n}^{\circ} 608001$, 'ABYSS'. Some of the samples and measurements shown in this study were taken as part of a course (GEO-FYS4200/9200, 2014) at the University of Oslo, and the authors thank Jonas Thu Olsen, Owais Hameed, Connie Lium Selmo, and Taher Rabizadeh for their contributions. Odd Nilsen and Muriel Erambert similarly contributed to fieldwork. We thank Manuel Menzel for helpful discussions and three anonymous reviewers for their constructive criticism.

\section{References}

Alt,J.C. \& Shanks, W.C. 1998: Sulfur in serpentinized oceanic peridotites: Serpentinization processes and microbial sulfate reduction. Journal of Geophysical Research: Solid Earth 103, 9917-9929. https://doi.org/10.1029/98JB00576.

Andreani, M., Grauby, O., Baronnet, A. \& Muñoz, M. 2008: Occurrence, composition and growth of polyhedral serpentine. European Journal of Mineralogy 20,159-171.

https://doi.org/10.1127/0935-1221/2008/0020-1801.

Barnes, I., O’Neil, J. \& Trescases, J.-J. 1978: Present day serpentinization in New Caledonia, Oman and Yugoslavia. Geochimica et Cosmochimica Acta 42, 144-145. https://doi.org/10.1016/0016-7037(78)90225-9.

Beard, J.S. \& Hopkinson, L. 2000: A fossil, serpentinization-related hydrothermal vent, Ocean Drilling Program Leg 173, Site 1068 (Iberia Abyssal Plain): Some aspects of mineral and fluid chemistry. Journal of Geophysical Research: Solid Earth 105, 16527-16539. https://doi.org/10.1029/2000JB900073.

Beinlich, A. \& Austrheim, H. 2012: In situ sequestration of atmospheric $\mathrm{CO} 2$ at low temperature and surface cracking of serpentinized peridotite in mine shafts. Chemical Geology 332-333, 32-44. https://doi.org/10.1016/j.chemgeo.2012.09.015.

Beinlich, A., Austrheim, H., Glodny, J., Erambert, M. \& Andersen, T.B. 2010: $\mathrm{CO}_{2}$ sequestration and extreme $\mathrm{Mg}$ depletion in serpentinized peridotite clasts from the Devonian Solund basin, SW-Norway. Geochimica et Cosmochimica Acta 74, 6935-6964. https://doi.org/10.1016/j.gca.2010.07.027.

Beinlich, A., Austrheim, H., Mavromatis, V., Grguric, B., Putnis, C.V. \& Putnis, A. 2018: Peridotite weathering is the missing ingredient of Earth's continental crust composition. Nature Communications 9:634. https://doi.org/10.1038/s41467-018-03039-9.

Bernoulli, D. \& Weissert, H. 1985: Sedimentary fabrics in Alpine ophicalcites, South Pennine Arosa zone, Switzerland. Geology 13, 755-758.

https://doi.org/10.1130/0091-7613(1985)13<755:SFIAOS>2.0.CO;2.

Boillot, G. \& Froitzheim, N. 2001: Non-volcanic rifted margins, continental break-up and the onset of sea-floor spreading: some outstanding questions. Geological Society of London Special Publications 187, 9-30.

https://doi.org/10.1144/GSL.SP.2001.187.01.02.

Bonatti, E., Lawrence, J.R., Hamlyn, P.R. \& Breger, D. 1980: Aragonite from deep sea ultramafic rocks. Geochimica et Cosmochimica Acta 44, 1207-1214. https://doi.org/10.1016/0016-7037(80)90074-5.

Burton, E.A. \& Walter, L.M. 1987: Relative precipitation rates of aragonite and $\mathrm{Mg}$ calcite from seawater: Temperature or carbonate ion control? Geology 15, 111-114.

https://doi.org/10.1130/0091-7613(1987)15<111:RPROAA >2.0.CO;2.

Clerc, C., Boulvais, P., Lagabrielle, Y. \& de Saint Blanquat, M. 2014: Ophicalcites from the northern Pyrenean belt: a field, petrographic and stable isotope study. International Journal of Earth Sciences 103, 141-163. https://doi.org/10.1007/s00531-013-0927-z.
Comas, M., Sánchez-Gómez, M., Cornen, G. \& De Kaenel, E. 1996: Serpentinized peridotite breccia and olistostrome on basement highs of the Iberia Abyssal Plain: implications for tectonic margin evolution. In Whitmarsh, R.B., Sawyer, D.S., Klaus, A. \& Masson, D.G. (eds.): Proceedings of the ODP, Scientific Res ults 149, Ocean Drilling Program, College Station, TX, pp. 577-594.

https://doi.org/10.2973/odp.proc.sr.149.228.1996.

del Real, P.G., Maher, K., Kluge, T., Bird, D.K., Brown Jr., G.E. \& John, C.M. 2016: Clumped-isotope thermometry of magnesium carbonates in ultramafic rocks. Geochimica et Cosmochimica Acta 193, 222-250. https://doi.org/10.1016/j.gca.2016.08.003.

Eickmann, B., Bach, W. \& Peckmann, J. 2009: Authigenesis of carbonate minerals in modern and Devonian ocean-floor hard rocks. The Journal of Geology 117, 307-323. https://doi.org/10.1086/597362.

Fallick, A.E., Ilich, M. \& Russell, M.J. 1991: A stable isotope study of the magnesite deposits associated with the alpine-type ultramafic rocks of Yugoslavia. Economic Geology 86, 847-861. https://doi.org/10.2113/gsecongeo.86.4.847.

Früh-Green, G., Weissert, H. \& Bernoulli, D. 1990: A multiple fluid history recorded in Alpine ophiolites. Journal of the Geological Society 147, 959-970. https://doi.org/10.1144/gsjgs.147.6.0959.

Goldschmidt, V. 1913: Das Devongebiet am Röragen bei Röros. Mit einem palæobotanischen Beitrag: Die Pflanzenreste der RöragenAbagerung, von A. G. Nathorst. Videnskapsselskapet i Kristiania Skrifter 9, 1-27.

Hövelmann, J., Austrheim, H., Beinlich, A. \& Anne Munz, I. 2011: Experimental study of the carbonation of partially serpentinized and weathered peridotites. Geochimica et Cosmochimica Acta 75, 6760-6779. https://doi.org/10.1016/j.gca.2011.08.032.

Iyer, K., Austrheim, H., John, T. \& Jamtveit, B. 2008: Serpentinization of the oceanic lithosphere and some geochemical consequences: Constraints from the Leka Ophiolite Complex, Norway. Chemical Geology 249, 66-90. https://doi.org/10.1016/j.chemgeo.2007.12.005.

Jamtveit, B. \& Hammer, Ø. 2012: Sculpting of rocks by reactive fluids. Geochemical Perspectives 1, 341-481. https://doi.org/10.7185/geochempersp.1.3.

Kaczmarek, S.E. \& Sibley, D.F. 2011: On the evolution of dolomite stoichiometry and cation order during high-temperature synthesis experiments: An alternative model for the geochemical evolution of natural dolomites. Sedimentary Geology 240, 30-40. https://doi.org/10.1016/j.sedgeo.2011.07.003.

Kelemen, P.B. \& Matter, J. 2008: In situ carbonation of peridotite for $\mathrm{CO}_{2}$ storage. Proceedings of the National Academy of Sciences 105, 17295-17300. https://doi.org/10.1073/pnas.0805794105.

Kelley, D.S., Karson, J.A., Früh-Green, G.L., Yoerger, D.R., Shank, T.M., Butterfield, D.A., Hayes, J.M., Schrenk, M.O., Olson, E.J., Proskurowski, G., Jakuba, M., Bradley, A., Larson, B., Ludwig, K., Glickson, D., Buckman, K., Bradley, A.S., Brazelton, W.J., Roe, K., Elend, M.J., Delacour, A., Bernasconi, S.M., Lilley, M.D., Baross, J.A., Summons, R.E. \& Sylva, S.P. 2005: A Serpentinite-Hosted Ecosystem: The Lost City Hydrothermal Field. Science 307, 1428-1434. https://doi.org/10.1126/science.1102556.

Ludwig, K.A., Kelley, D.S., Butterfield, D.A., Nelson, B.K. \& Früh-Green, G. 2006: Formation and evolution of carbonate chimneys at the Lost City Hydrothermal Field. Geochimica et Cosmochimica Acta 70, 3625-3645. https://doi.org/10.1016/j.gca.2006.04.016.

Marini, L. 2007: Geological Sequestration of Carbon Dioxide: Thermodynamics, Kinetics, and Reaction Path Modeling. Elsevier, pp. $1-453$.

Menzel, M.D., Garrido, C.J., López Sánchez-Vizcaíno, V., Marchesi, C., Hidas, K., Escayola, M.P. \& Delgado Huertas, A. 2018: Carbonation of mantle peridotite by $\mathrm{CO}_{2}$-rich fluids: the formation of listvenites in the Advocate ophiolite complex (Newfoundland, Canada). Lithos 323, 238-261. https://doi.org/10.1016/j.lithos.2018.06.001. 
Mervine, E.M., Humphris, S.E., Sims, K.W.W., Kelemen, P.B. \& Jenkins, W.J. 2014: Carbonation rates of peridotite in the Samail Ophiolite, Sultanate of Oman, constrained through ${ }^{14} \mathrm{C}$ dating and stable isotopes. Geochimica et Cosmochimica Acta 126, 371-397. https://doi.org/10.1016/j.gca.2013.11.007.

Milliken, K.L. \& Morgan, J.K. 1996: Chemical Evidence For NearSeafloor Precipitation of Calcite in Serpentinites (Site 897) and Serpentinite Breccias (Site 899), Iberia Abyssal Plain. In Whitmarsh, R.B., Sawyer, D.S., Klaus, A. \& Masson, D.G. (eds.): Proceedings of the ODP, Scientific Results 149, Ocean Drilling Program, College Station, TX, pp. 553-558. https://doi.org/10.2973/odp.proc.sr.149.229.1996.

Moore, A.C.H. \& Hultin, I. 1980: Petrology, mineralogy, and origin of the Feragen ultramafic body, Sør-Trøndelag, Norway. Norsk Geologisk Tidsskrift 60, 235-254.

Morgan, J.K. \& Milliken, K.L. 1996: Petrography of calcite veins in serpentinized peridotite basement rocks from the Iberia abyssal plain, sites 897 and 899; kinematic and environmental implications. In Whitmarsh, R.B., Sawyer, D.S., Klaus, A. \& Masson, D.G. (eds.): Proceedings of the ODP, Scientific Results 149, Ocean Drilling Program, College Station, TX, pp. 559-569. https://doi.org/10.2973/odp.proc.sr.149.230.1996.

Morse, J.W., Arvidson, R.S. \& Lüttge, A. 2007: Calcium carbonate formation and dissolution. Chemical reviews 107, 342-381. https://doi.org/10.1021/cr050358j.

Mucci, A. \& Morse, J.W. 1983: The incorporation of $\mathrm{Mg}^{2+}$ and $\mathrm{Sr}^{2+}$ into calcite overgrowths: influences of growth rate and solution composition. Geochimica et Cosmochimica Acta 47, 217-233. https://doi.org/10.1016/0016-7037(83)90135-7.

Neal, C. \& Stanger, G. 1984: Calcium and magnesium hydroxide precipitation from alkaline groundwaters in Oman, and their significance to the process of serpentinization. Mineralogical Magazine 48, 237-241. https://doi.org/10.1180/minmag.1984.048.347.07.

Neal, C. \& Stanger, G. 1985: Past And Present Serpentinisation of Ultramafic Rocks; An Example from the Semail Ophiolite Nappe of Northern Oman. In Drever, J.I. (ed.): The Chemistry of Weathering, NATO Science Series C 149, Springer, Dordrecht, pp. 249-275. https://doi.org/10.1007/978-94-009-5333-8_15.

Nilsson, L.P., Sturt, B.A. \& Ramsay, D.M. 1997: Ophiolitic ultramafites in the Folldal-Røros tract, and their Cr-(PGE) mineralisation (Extended abstract). Norges geologiske undersøkelse Bulletin 433, $10-11$.

Nilsson, L.P., Roberts, D. \& Ramsay, D.M. 2005: The Raudfellet ophiolite fragment, Central Norwegian Caledonides: pricipal lithological and structural features. Norges geologiske undersøkelse Bulletin 445, 101117.

Nilsson, L.P. \& Roberts, D. 2014: A trail of ophiolitic debris and its detritus along the Trøndelag-Jämtland border: correlations and palaeogreographical implications. Norges geologiske undersøkelse Bulletin 453, 29-41.

Oskierski, H.C., Dlugogorski, B.Z. \& Jacobsen, G. 2013: Sequestration of atmospheric $\mathrm{CO}_{2}$ in a weathering-derived, serpentinite-hosted magnesite deposit: ${ }^{14} \mathrm{C}$ tracing of carbon sources and age constraints for a refined genetic model. Geochimica et Cosmochimica Acta 122, 226-246. https://doi.org/10.1016/j.gca.2013.08.029.

Palandri, J.L. \& Reed, M.H. 2004: Geochemical models of metasomatism in ultramafic systems: serpentinization, rodingitization, and sea floor carbonate chimney precipitation. Geochimica et Cosmochimica Acta 68, 1115-1133. https://doi.org/10.1016/j.gca.2003.08.006.

Picazo, S., Manatschal, G., Cannat, M. \& Andréani, M. 2013: Deformation associated to exhumation of serpentinized mantle rocks in a fossil Ocean Continent Transition: The Totalp unit in SE Switzerland. Lithos 175-176, 255-271.

https://doi.org/10.1016/j.lithos.2013.05.010.

Pohl, W. 1990: Genesis of magnesite deposits - models and trends. Geologische Rundschau 79, 291-299.

https://doi.org/10.1007/BF01830626.
Roberts, D. 1974: Sedimentary, tectonic and metamorphic features of the Devonian of Røragen, Sør-Trøndelag. Norges geologiske undersøkelse Bulletin 311, 89-108.

Ross, D.J. 1991: Botryoidal high-magnesium calcite marine cements from the Upper Cretaceous of the Mediterranean region. Journal of Sedimentary Research 61,349-353.

https://doi.org/10.1306/D4267708-2B26-11D7-8648000102C1865D.

Schroll, E. 2002: Genesis of magnesite deposits in the view of isotope geochemistry. Boletim paranaense de geociencias 50, 59-68. https://doi.org/10.5380/geo.v50i0.4158.

Schwarzenbach, E.M., Früh-Green, G.L., Bernasconi, S.M., Alt, J.C. \& Plas, A. 2013: Serpentinization and carbon sequestration: A study of two ancient peridotite-hosted hydrothermal systems. Chemical Geology 351, 115-133.

https://doi.org/10.1016/j.chemgeo.2013.05.016.

Schwarzenbach, E.M., Gill, B.C., Gazel, E. \& Madrigal, P. 2016: Sulfur and carbon geochemistry of the Santa Elena peridotites: Comparing oceanic and continental processes during peridotite alteration. Lithos 252, 92-108. https://doi.org/10.1016/j.lithos.2016.02.017.

Searl, A. 1992: Dolomite-carbonate replacement textures in veins cutting Carboniferous rocks in East Fife. Sedimentary Geology 77, 1-14. https://doi.org/10.1016/0037-0738(92)90100-6.

Séguret, M., Séranne, M., Chauvet, A. \& Brunel, A. 1989: Collapse basin: A new type of extensional sedimentary basin from the Devonian of Norway. Geology 17, 127-130.

https://doi.org/10.1130/0091-7613(1989)017<0127:CBANTO>2.3.CO;2.

Sibley, D.F., Dedoes, R.E. \& Bartlett, T.R. 1987: Kinetics of dolomitization. Geology 15, 1112-1114.

https://doi.org/10.1130/0091-7613(1987)15<1112:KOD>2.0.CO;2.

Sunagawa, I., Takahashi, Y. \& Imai, H. 2007: Strontium and aragonitecalcite precipitation. Journal of Mineralogical and Petrological Sciences 102, 174-181. https://doi.org/10.2465/jmps.060327a.

Veizer, J., Ala, D., Azmy, K., Bruckschen, P., Buhl, D., Bruhn, F., Carden, G.A., Diener, A., Ebneth, S. \& Godderis, Y. $1999:{ }^{87} \mathrm{Sr} /{ }^{86} \mathrm{Sr}, \delta^{13} \mathrm{C}$ and $\delta^{18} \mathrm{O}$ evolution of Phanerozoic seawater. Chemical Geology 161, 5988. https://doi.org/10.1016/S0009-2541(99)00081-9.

Zedef, V., Russell, M.J., Fallick, A.E. \& Hall, A.J. 2000: Genesis of Vein Stockwork and Sedimentary Magnesite and Hydromagnesite Deposits in the Ultramafic Terranes of Southwestern Turkey: A Stable Isotope Study. Economic Geology 95, 429-445.

https://doi.org/10.2113/gsecongeo.95.2.429. 